\title{
Carbon isotopic composition of branched tetraether membrane lipids in soils suggest a rapid turnover and a heterotrophic life style of their source organism(s)
}

\author{
J. W. H. Weijers ${ }^{1,2, *}$, G. L. B. Wiesenberg ${ }^{3}$, R. Bol ${ }^{4}$, E. C. Hopmans ${ }^{5}$, and R. D. Pancost ${ }^{1}$ \\ ${ }^{1}$ Bristol Biogeochemistry Research Centre, Organic Geochemistry Unit, School of Chemistry, University of Bristol, \\ Bristol BS8 1TS, UK \\ ${ }^{2}$ Department of Earth Sciences, Utrecht University, P. O. Box 80.021, 3508 TA Utrecht, The Netherlands \\ ${ }^{3}$ Department of Agroecosystem Research, University of Bayreuth, 95440 Bayreuth, Germany \\ ${ }^{4}$ Sustainable Soils and Grassland Systems Dept., Rothamsted Research, North Wyke, Okehampton, Devon, EX20 2SB, UK \\ ${ }^{5}$ Department of Marine Organic Biogeochemistry, Royal Netherlands Institute for Sea Research (NIOZ), P. O. Box 59, \\ 1790 AB Den Burg-Texel, The Netherlands
}

*Invited contribution by J. W. H. Weijers, recipient of the EGU Arne Richter Award for Outstanding Young Scientists 2009.

Received: 7 May 2010 - Published in Biogeosciences Discuss.: 21 May 2010

Revised: 1 September 2010 - Accepted: 3 September 2010 - Published: 28 September 2010

\begin{abstract}
Branched Glycerol Dialkyl Glycerol Tetraethers (GDGTs) are membrane spanning lipids synthesised by as yet unknown bacteria that thrive in soils and peat. In order to obtain more information on their ecological niche, the stable carbon isotopic composition of branched GDGT-derived alkanes, obtained upon ether bond cleavage, has been determined in a peat and various soils, i.e. forest, grassland and cropland, covered by various vegetation types, i.e., $\mathrm{C}_{3}$ vs. $\mathrm{C}_{4}$-plant type. These $\delta^{13} \mathrm{C}$ values are compared with those of bulk organic matter and higher plant derived $n$ alkanes from the same soils. With average $\delta^{13} \mathrm{C}$ values of $-28 \%$, branched GDGTs in $\mathrm{C}_{3}$ soils are only slightly depleted (ca. 1\%o) relative to bulk organic carbon and on average $8.5 \%$ enriched relative to plant wax-derived long-chain $n$-alkanes $\left(n \mathrm{C}_{29}-n \mathrm{C}_{33}\right)$. In an Australian soil dominantly covered with $\mathrm{C}_{4}$ type vegetation, the branched GDGTs have a $\delta^{13} \mathrm{C}$ value of $-18 \%$, clearly higher than observed in soils with $\mathrm{C}_{3}$ type vegetation. As with $\mathrm{C}_{3}$ vegetated soils, branched GDGT $\delta^{13} \mathrm{C}$ values are slightly depleted (1\%o) relative to bulk organic carbon and enriched (ca. 5\%o) relative to $n$-alkanes in this soil. The $\delta^{13} \mathrm{C}$ values of branched GDGT lipids being similar to bulk organic carbon and their
\end{abstract}

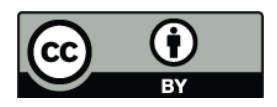

Correspondence to: J. W. H. Weijers (j.weijers@geo.uu.nl) co-variation with those of bulk organic carbon and plant waxes, suggest a heterotrophic life style and assimilation of relatively heavy and likely labile substrates for the as yet unknown soil bacteria that synthesise the branched GDGT lipids. However, a chemoautotrophic lifestyle, i.e. consuming respired $\mathrm{CO}_{2}$, could not be fully excluded based on these data alone. Based on a natural labelling experiment of a $\mathrm{C}_{3} / \mathrm{C}_{4}$ crop change introduced on one of the soils 23 years before sampling and based on a free-air $\mathrm{CO}_{2}$ enrichment experiment with labelled $\mathrm{CO}_{2}$ on another soil, a turnover time of ca. 18 years has been estimated for branched GDGTs in these arable soils.

\section{Introduction}

Branched glycerol dialkyl glycerol tetraethers (GDGTs; IIX in Fig. 1) are microbially derived membrane lipids that were first inferred to exist based on the presence of unexpected branched alkanes in $\mathrm{BBr}_{3}$-treated (ether-cleaved) Messel Shale sediments (Chappe et al., 1979). The core tetraether comprises $\mathrm{C}_{28}$ alkyl moieties with methylation at the C-13 and C-16 positions (Sinninghe Damsté et al., 2000). Structural variation in branched GDGTs occurs by additional methylation at the C-5 position and the occurrence of one or two cyclopentyl moieties (Weijers et al., 2006a). A bacterial

Published by Copernicus Publications on behalf of the European Geosciences Union. 


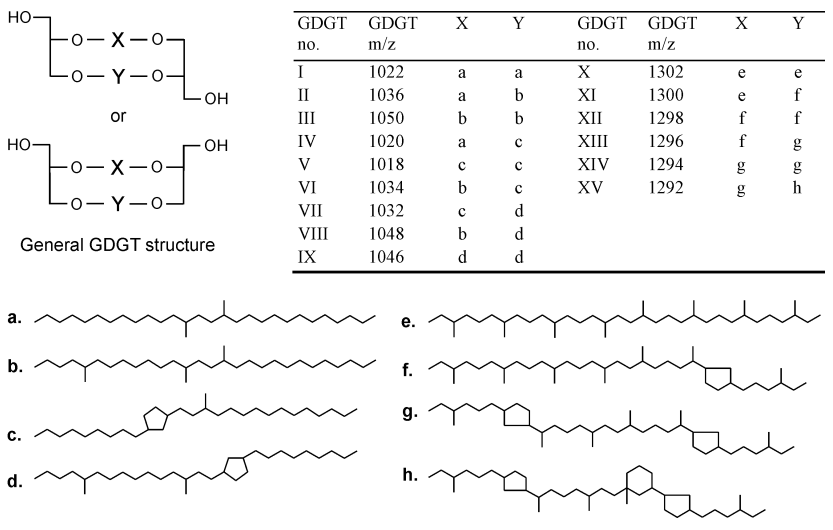

Fig. 1. Structures of the branched glycerol dialkyl glycerol tetraether (GDGT) membrane lipids (I-IX) and the isoprenoid GDGTs $(\mathrm{X}-\mathrm{XV})$. GDGT $\mathrm{X}$ is also referred to as GDGT-0 and GDGT XV is known as crenarchaeol. The alkyl moieties (a-h) are located at positions $\mathrm{X}$ and $\mathrm{Y}$ in the general GDGT structure (these positions are interchangeable) and are released upon chemical cleavage of the ether bond. GDGT structures can also occur as a stereoisomer of the general structure, i.e. parallel and anti-parallel configuration of the alcohol groups.

origin of branched GDGTs was eventually postulated, based on the stereochemical configuration of the glycerol backbone (Weijers et al., 2006a). Branched GDGTs are abundant in peat bogs and have been reported in virtually every soil for which they have been specifically analysed, although concentrations can vary to a large extent (e.g. Kim et al., 2006; Weijers et al., 2006a, b). The total concentration of branched GDGTs seems to be determined primarily by organic carbon content and soil $\mathrm{pH}$, whereas differences in the distributions of specific GDGTs are most strongly related to soil $\mathrm{pH}$ and temperature (Weijers et al., 2006b, 2007; Peterse et al., 2009).

So far, the branched GDGTs still are the molecular coelacanths waiting for a living "avatar" (Chappe et al., 1979) and as such the ecological niche of the source bacteria remains enigmatic. As branched GDGT concentrations are much higher in the water-saturated, and thus, anoxic part of peat bogs (catotelm) than in the partly oxygenated upper horizon (i.e., acrotelm, Weijers et al., 2006a), their source organisms are likely anaerobic bacteria. A combined organic geochemical and microbiological analysis of a $50 \mathrm{~cm}$ peat core from a Swedish ombrotrophic bog hints to the Acidobacteria as the phylum potentially containing GDGT-synthesising bacteria (Weijers et al., 2009). Unfortunately, only very few cultured bacteria are available from this large phylum hampering a proper screening of the Acidobacteria for these compounds.

The carbon isotopic composition of an organism is primarily dictated by the isotopic composition of the source carbon and the mechanism by which this carbon is assimilated. These are, in turn, related to the ecology of an organism (e.g. Pancost and Sinninghe Damsté, 2003). Lipids of chemoautotrophic microorganisms oxidizing methane, for example, generally have low $\delta^{13} \mathrm{C}$ values (e.g. Brassell et al., 1981; Summons et al., 1998). In contrast, lipids of heterotrophic organisms involved in fermentation of organic matter, are generally assumed to resemble the carbon isotopic composition of this organic matter (e.g. Hayes, 1993), although variability exists (e.g. Zhang et al., 2003). These ${ }^{13} \mathrm{C}$ values could, in turn, be different again from the lipid carbon isotopic composition of autotrophic microbes that utilise $\mathrm{CO}_{2}$ as their primary carbon source, e.g. Cyanobacteria (e.g. Sakata et al., 1997). In the absence of cultured species of branched GDGT-synthesising bacteria, the carbon isotopic composition of branched GDGT lipids in the environment might, thus, provide additional information on the ecological role of the source organisms. This is important for two reasons. First, based on the abundance of branched GDGT lipids in soils and peats, these microorganisms seem to be an important constituent of soil ecosystems, however, we do not know what processes they are involved in. Second, information on the ecology of branched GDGT-synthesising bacteria might aid in a better interpretation of proxy records based on these compounds, for example, whether or not preferential seasonal activity might cause a bias in temperature records reconstructed using the relative abundance of these compounds (Weijers et al., 2007).

Thus far, only three studies reported the carbon isotopic composition of branched GDGTs (Pancost and Sinninghe Damsté, 2003; Smittenberg et al., 2005; Oppermann et al., 2010). The foremost reason for such few studies is that GDGT lipids themselves are not GC-amenable, and carbon isotopic determinations typically require either offline isolation (using, for example, preparatory liquid chromatography) of GDGTs or the chemical cleavage of the ether bonds, thereby releasing the GC-amenable octacosane components. It should be noted that the second approach does not incorporate the carbon isotopic composition of the glycerol component of the GDGTs. The glycerol units, however, comprise fewer than $10 \%$ of the carbon atoms of the whole tetraether. Using the first approach, Smittenberg et al. (2005) reported $\delta^{13} \mathrm{C}$ values of $-28.4 \%$ and $-28.6 \%$ in sediment samples from Drammensfjord, Norway. These branched GDGT are most likely derived from forested soils in the catchment of the Drammen river and soils directly surrounding the fjord (Huguet et al., 2007). Using the chemical cleavage of ether bonds, Pancost and Sinninghe Damsté (2003) reported $\delta^{13} \mathrm{C}$ values of 13,16-dimethyloctacosane to be ca. $-29 \%$, based on 8 samples from the Bargerveen peat bog, The Netherlands. Although not diagnostic, comparison to other organic matter pools led the authors to speculate that the source organism is either a fermentative bacterium acting as intermediate between aerobic heterotrophs and methanogens or an as yet uncharacterised methanogenic archaeon. The latter, however, seems implausible as a bacterial origin of the branched GDGTs has now been more firmly established. Following a similar protocol, recently, Oppermann et al. (2010) reported 
a carbon isotopic value of ca. $-31 \%$ for branched GDGT derived alkanes in a control soil near a $\mathrm{CO}_{2}$ vent.

To expand the range of environments for which GDGT $\delta^{13} \mathrm{C}$ values are known, we investigated a set of various soils and an additional peat. Following ether-bond cleavage, the isotopic composition of the branched alkane components of GDGTs were determined and compared to the $\delta^{13} \mathrm{C}$ values of total organic carbon (TOC) and the $\delta^{13} \mathrm{C}$ values of plant wax-derived long chain $n$-alkanes, which are relatively recalcitrant compounds of the TOC. These values are used to test proposed metabolisms of the source organisms. Due to the presence of two natural labelling experiments in the dataset, i.e. a $\mathrm{C}_{3}-\mathrm{C}_{4}$ crop change and a Free-Air $\mathrm{CO}_{2}$ Enrichment (FACE) experiment using ${ }^{13} \mathrm{C}$ depleted $\mathrm{CO}_{2}$, the stable carbon isotopic composition of branched GDGTs in these soils could also be used to estimate the turnover time of branched GDGTs. In addition, where possible, carbon isotopic compositions of the common isoprenoid GDGT-0 (X in Fig. 1), derived from a range of archaea, and of crenarchaeol (XV), derived from soil Crenarchaeota, have been determined for comparison.

\section{Site descriptions}

Four soils were obtained from the long-term experiment of the "Höhere Landbauschule" at Rotthalmünster, Germany $\left(\mathrm{N} 48^{\circ} 21^{\prime} 47^{\prime \prime}, \mathrm{E} 13^{\circ} 11^{\prime} 46^{\prime \prime}\right)$. The soil type at this site is a loess-derived stagnic Luvisol with a silty loam texture. Soil samples were taken from: (i) a continuous wheat plot (Triticum aestivum L.) established on a former grassland in 1969; (ii) a continuous maize plot (Zea mays L.) where only grains were harvested; prior to establishment of the maize culture in 1979, this plot was grassland until 1970 followed by wheat cultivation; (iii) a grassland established in 1961; and (iv) a nearby forest soil from a ca. 80 year old spruce stand (Picea abies L.). The wheat, maize and grassland plots were fertilized with 171,180 and $160 \mathrm{~kg} \mathrm{Nha}^{-1} \mathrm{yr}^{-1}$, respectively. More details on the site and soils are provided by John et al. (2005). All soils were sampled in September 2002; the wheat and maize cropped soils from a depth interval of $0-30 \mathrm{~cm}$, the grassland soil from a depth of $0-10 \mathrm{~cm}$ and the forest soil was sampled from a $0-7 \mathrm{~cm}$ depth interval.

Two additional $\mathrm{C}_{3}$-type soils were obtained from the UK. The first is a grassland soil from the long term experimental research platform site at Rowden Moor (Devon, SW England). The clayey pelo-stagnogley soil from the Hallsworth series (classified as a Stagni-vertic Cambisol in the FAO system) has a silty clay texture and remains very wet from autumn until early spring due to the virtually impermeable clay layer at $30 \mathrm{~cm}$ depth (Harrod and Hogan, 2008). The vegetation consists of Lolium perenne with patches of Juncus effuses. Five small $30-\mathrm{cm}$ long cores were taken in February 2008 in an X-shape and sliced in 10-cm increments. Similar depth increments were pooled and homogenized, resulting in three composite samples spanning the top $30 \mathrm{~cm}$. A second soil was sampled from a beech and oak dominated deciduous forest in Leigh Woods, along the Avon Gorge near the city of Bristol, UK. These forests represent some of the oldest (150-250 yrs) woodlands in the South West of England and have been designated a National Nature Reserve. The soil, a brown ranker falling within the Crwbin association, is a well-drained loamy brown earth with a clayish silty texture mixed with coarse limestone gravel and has developed on carboniferous limestone. The soil was sampled in November 2007 at a $3-15 \mathrm{~cm}$ depth interval.

$\mathrm{A} \mathrm{C}_{4}$-grassland soil was obtained from an open, mixed woodland-grassland site in the "Blue Range" study area located $130 \mathrm{~km}$ north-west of Charters Towers, Queensland, Australia $\left(19^{\circ} 09^{\prime} \mathrm{S}, 145^{\circ} 24^{\prime} \mathrm{E}\right)$, within the catchment of the Burdekin River. The site is an uncleared, remnant woodland consisting of a mosaic of open grassy areas and more densely wooded areas. The main vegetation type is eucalyptus woodland (Eucalyptus crebra; $\mathrm{C}_{3}$-type vegetation), but the groundcover was dominated by Urochloa (Urochloa mosambicencis) and Chrysopogon (Chrysopogon fallax) grasses ( $\mathrm{C}_{4}$-type). More details on the site and soil are given in Krull and Bray (2005). The soil analysed was sampled from an open site dominated by $\mathrm{C}_{4}$-type grass vegetation in June 2002 at a depth interval of $0-20 \mathrm{~cm}$.

A peat was sampled at $34-38 \mathrm{~cm}$ depth, i.e. the catotelm, from a mesotrophic mire in the Stordalen mire in northern Sweden $\left(68^{\circ} 21^{\prime} \mathrm{N}, 18^{\circ} 49^{\prime} \mathrm{E}\right)$ near the village of Abisko. The site is situated at $385 \mathrm{~m}$ a.s.l., ca. $200 \mathrm{~km}$ north of the Arctic Circle and is characterised by discontinuous permafrost. The vegetation on this mire is dominated by Sphagnum species.

A soil from a free-air $\mathrm{CO}_{2}$ enrichment (FACE) study plus a control soil from the same plot were obtained from the Swiss Federal Institute of Technology (ETH) experimental trial near Eschikon, $20 \mathrm{~km}$ north-east of Zürich, Switzerland. The soil, classified as Eutric Cambisol (FAO) was covered by clover (Trifolium repens L.) and on neighbouring plots experienced either ambient (ca. $360 \mathrm{ppm}$ on average) or elevated (ca. $600 \mathrm{ppm}$ ) atmospheric $\mathrm{CO}_{2}$ concentrations for 10 years. The $\delta^{13} \mathrm{C}$ value of the added $\mathrm{CO}_{2}$ was ca. $-48 \%$ o. Mixed with atmospheric $\mathrm{CO}_{2}$ this resulted in a $\delta^{13} \mathrm{C}$ value of the $\mathrm{CO}_{2}$ above the plot of $-18 \%$, significantly lower than that of atmospheric $\mathrm{CO}_{2}(-8 \%$ o). For experimental details see Zanetti et al. (1997). The sampled plots received $\mathrm{N}$-fertilization of ca. $140 \mathrm{~kg} \mathrm{~N} \mathrm{ha}^{-1} \mathrm{yr}^{-1}$. Samples were taken in summer 2002 after the termination of the FACE experiment and combined with corresponding samples from replicate plots and homogenized. For this study, samples from the top soil layer $(0-$ $10 \mathrm{~cm}$ ) have been used. 


\section{Methods}

\subsection{Bulk analyses}

Total organic carbon content (TOC\%) of dried soil samples was determined after removal of the inorganic carbon with $1 \mathrm{M} \mathrm{HCl}$, using a Fisons Instruments NA1500-NCS elemental analyzer. The carbon isotopic composition of TOC $\left(\delta^{13} \mathrm{C}_{\mathrm{toc}}\right.$, in per mill notation relative to the Vienna Pee Dee Belemnite standard) has been determined using a ThermoFinnigan Delta ${ }^{\text {Plus }}$ isotope ratio mass spectrometer, with an internal precision of $0.07 \%$, which is coupled to the elemental analyzer via a Finnigan MAT ConFlo II continuous flow system interface.

\subsection{Extraction}

Depending on availability of sample material and TOC content, up to $45 \mathrm{~g}$ of freeze-dried and ground soil material has been extracted ultrasonically using Methanol $(\mathrm{MeOH})$, Dichloromethane (DCM):MeOH 1:1 (v/v) and DCM solvents, sequentially, 3 times each for $15 \mathrm{~min}$, or with a Soxhlet system for $24 \mathrm{~h}$ using a solvent mixture of DCM:MeOH 2:1 (v/v) (Table 1). The obtained total extracts were concentrated by rotary evaporation and remaining clay particles were removed by eluting over small columns plugged with pre-extracted cotton wool. The extracts were then separated over a column packed with activated $\mathrm{Al}_{2} \mathrm{O}_{3}$ into a nominally apolar fraction by eluting with DCM and a polar fraction by eluting with a DCM:MeOH 95:5 (v/v) azeotrope. The polar fraction, containing the GDGT lipids, was dried under a gentle $\mathrm{N}_{2}$ stream, ultrasonically redissolved in $n$ hexane:propanol 99:1 (v/v) to a concentration of ca. $2 \mathrm{mg} / \mathrm{ml}$ and filtered over a $0.45 \mu \mathrm{m}$ mesh PTFE filter (Alltech).

\subsection{HPLC/MS}

Small aliquots of the polar fractions were analysed for their GDGT content using high performance liquid chromatography - mass spectrometry (HPLC/MS) on an Agilent 1100 series/Hewlett-Packard 1100 MSD series machine equipped with HP Chemstation software according to Hopmans et al. (2000) with some modifications. Separation of GDGTs was achieved on an analytical Alltech Prevail Cyano column $(150 \mathrm{~mm} \times 2.1 \mathrm{~mm}, 3 \mu \mathrm{m})$ with $n$-hexane:propanol 99:1 (v/v) as eluent (flow rate $0.2 \mathrm{ml} \mathrm{min}^{-1}$ ), isocratically for the first 5 min, thereafter with a linear gradient to $1.8 \%$ propanol in $45 \mathrm{~min}$. Detection was performed in selected ion monitoring (SIM) mode for the masses of interest. Quantification of GDGTs was achieved by integrating the $[\mathrm{M}+\mathrm{H}]^{+}$(protonated mass) peak areas and comparison with an external standard curve based on injections of known amounts of crenarchaeol, under the assumption of a 1:1 response factor ratio (on a molar basis) between crenarchaeol and branched GDGTs.

\subsection{Purification}

GDGT fractions were obtained using semi-preparative HPLC (see Smittenberg et al., 2002). In short, by means of multiple injections, a sample was separated over a semipreparative Alltech Prevail Cyano column $(250 \mathrm{~mm} \times 10 \mathrm{~mm}$; $5 \mu \mathrm{m})$ with a flow rate of $3 \mathrm{ml} \mathrm{min}^{-1}$, eluting isocratically with a $n$-hexane:propanol 99:1 (v/v) mixture for the first 5 $\mathrm{min}$, thereafter increasing to $1.8 \%$ propanol in $45 \mathrm{~min}$. The eluent was collected in $1 \mathrm{~min}$ fractions into collection vials using a Foxy Junior fraction collector (Isco, Lincoln, NE, USA). Flow injection analysis into the mass spectrometer (Agilent 1100 MSD series) was used to determine which collection vials contained the GDGTs that were subsequently pooled and concentrated using rotary evaporation and dried under a gentle $\mathrm{N}_{2}$ flow.

\subsection{Ether bond cleavage}

The alkyl moieties of the GDGTs were released by cleaving the ether bonds that connect them to the glycerol backbone (e.g. Schouten et al., 1998). To this end, 4-5 ml HI (57 wt $\%$ ) were added to the purified GDGT fraction and refluxed for $1.5 \mathrm{~h}$ at $150^{\circ} \mathrm{C}$ under continuous stirring. After cooling, the sample was transferred, with $n$-hexane and bidistilled and extracted water, into a separatory funnel. The organic layer was washed twice with bi-distilled, extracted water, once with a $5 \mathrm{wt} \% \mathrm{Na}_{2} \mathrm{~S}_{2} \mathrm{O}_{3}$ solution and twice again with bi-distilled, extracted water. The organic phase was concentrated using rotary evaporation and dried over a small column packed with $\mathrm{Na}_{2} \mathrm{SO}_{4}$. The $\mathrm{HI}$ treated sample was then separated over a column packed with activated $\mathrm{Al}_{2} \mathrm{O}_{3}$ into an apolar fraction (released alkyl iodides) and a polar fraction (remaining polar compounds) using $n$-hexane:DCM 9:1 $(\mathrm{v} / \mathrm{v})$ and DCM:MeOH 1:1 (v/v) solvent mixtures, respectively. Subsequently, the alkyl iodides were converted to hydrocarbons using $\mathrm{LiAlH}_{4}$. To this end, the fraction was refluxed for $1.5 \mathrm{~h}$ at $150^{\circ} \mathrm{C}$ in ca. $4 \mathrm{ml} \mathrm{1,4-Dioxane} \mathrm{(stabilized)}$ with a spatula tip of added $\mathrm{LiAlH}_{4}$, with continuous stirring. After cooling, the excess $\mathrm{LiAlH}_{4}$ was neutralized by adding a few drops ethyl acetate, and the sample was centrifuged for $5 \mathrm{~min}$ at $2500 \mathrm{rpm}$. The supernatant was removed and transferred into a separatory funnel filled with $30 \mathrm{ml}$ bidistilled and extracted water and $0.5 \mathrm{ml} 5 \mathrm{~N} \mathrm{HCl}$. The test tube was rinsed 3 times with DCM which was, after centrifugation, also added to the separatory funnel. The 1,4-Dioxane/water mixture was washed three times with DCM. The DCM, containing the alkyl compounds, was taken out of the funnel, concentrated using rotary evaporation and dried over a small column packed with $\mathrm{Na}_{2} \mathrm{SO}_{4}$. 
Table 1. Soils used in this study, with concentrations of the different GDGT membrane lipids. I-IX are the branched GDGTs, X is the acyclic isoprenoid "GDGT-0" and XV is the cyclohexane-bearing isoprenoid GDGT "crenarchaeol". Roman numerals refer to Fig. 1.

\begin{tabular}{|c|c|c|c|c|c|c|c|c|c|c|c|c|c|}
\hline & \multirow[b]{2}{*}{$\begin{array}{l}\text { depth } \\
\text { (cm) }\end{array}$} & \multirow[b]{2}{*}{$\begin{array}{l}\text { TOC } \\
(\%)\end{array}$} & \multirow[b]{2}{*}{$\begin{array}{c}\text { sediment } \\
\text { extracted }(\mathrm{g})\end{array}$} & \multirow[b]{2}{*}{$\begin{array}{c}\text { extraction } \\
\text { method }\end{array}$} & \multicolumn{3}{|c|}{ Yield (ng/g dry weight sed.) } & \multicolumn{3}{|c|}{ Yield ( $\mu \mathrm{g} / \mathrm{g}$ TOC) } & \multicolumn{3}{|c|}{$\%$ of total } \\
\hline & & & & & I-IX & $\mathrm{X}$ & $\mathrm{XV}$ & I-IX & $\mathrm{X}$ & $\mathrm{XV}$ & I-IX & $\mathrm{X}$ & $X V$ \\
\hline \multicolumn{14}{|l|}{ Forest soil } \\
\hline Leigh Woods & $3-12$ & 14.9 & 2.2 & soxhlet & 2500 & 3 & 6 & 17 & $<0.1$ & $<0.1$ & 100 & 0 & 0 \\
\hline Rotthalmünster & $0-7$ & 4.0 & 20.1 & soxhlet & 420 & 3 & 0 & 11 & 0,1 & $<0.1$ & 99 & 1 & 0 \\
\hline \multicolumn{14}{|l|}{ Grassland soil } \\
\hline Rotthalmünster & $0-8$ & $2.5 *$ & 17.3 & ultrasonic & 82 & 4 & 26 & 3 & 0,2 & 1.0 & 73 & 4 & 23 \\
\hline Rowden I & $0-10$ & 5.7 & 10.2 & ultrasonic & 4800 & 410 & 1 & 84 & 7.2 & $<0.1$ & 92 & 8 & 0 \\
\hline Rowden II & $10-20$ & 3.7 & 10.3 & ultrasonic & 710 & 28 & 1 & 19 & 0.8 & $<0.1$ & 96 & 4 & 0 \\
\hline Rowden III & $20-30$ & 1.7 & 12.1 & ultrasonic & 270 & 5 & 1 & 16 & 0.3 & 0.1 & 98 & 2 & 0 \\
\hline \multicolumn{14}{|l|}{ Cropland soil } \\
\hline Rotthalmünster wheat & $0-30$ & 1.7 & 25.1 & soxhlet & 82 & 8 & 29 & 5 & 0.5 & 1.7 & 69 & 7 & 24 \\
\hline \multicolumn{14}{|l|}{ Peat soil } \\
\hline Stordalen mire & $34-38$ & 44.8 & 0.3 & soxhlet & 130000 & 1600 & $<0.5$ & 290 & 3.6 & $<0.1$ & 99 & 1 & 0 \\
\hline \multicolumn{14}{|l|}{ FACE soil } \\
\hline T. repens ambient $\mathrm{CO}_{2}$ & $0-10$ & 3.1 & 47 & soxhlet & 120 & 43 & 56 & 4 & 1.4 & 1.8 & 55 & 20 & 26 \\
\hline T. repens elevated $\mathrm{CO}_{2}$ & $0-10$ & 3.5 & 46 & soxhlet & 360 & 170 & 240 & 10 & 4.9 & 6.9 & 47 & 22 & 31 \\
\hline \multicolumn{14}{|l|}{$C_{4}$ vegetated soil } \\
\hline Blue Range & $0-20$ & 0.9 & 19.5 & ultrasonic & 38 & 2 & 1 & 4 & 0.2 & 0.1 & 93 & 5 & 2 \\
\hline Rotthalmünster maize & $0-30$ & 1.8 & 25.5 & soxhlet & 210 & 44 & 62 & 12 & 2.4 & 3.4 & 66 & 14 & 20 \\
\hline
\end{tabular}

* data from John et al. (2005)

\subsection{Analysis}

Released alkyl moieties were identified using a ThermoQuest TraceMS gas chromatograph mass spectrometer (GC-MS). Chromatographic separation was achieved using a Chrompack fused silica capillary column $(50 \mathrm{~m} \times 0.32 \mathrm{~mm}$ i.d.) coated with a CP Sil-5CB stationary phase (dimethylpolysiloxane equivalent, $0.12 \mu \mathrm{m}$ film thickness) and using $\mathrm{He}$ as the carrier gas; the following temperature program was used: $70^{\circ} \mathrm{C}(1 \mathrm{~min})$ to $130^{\circ} \mathrm{C}$ at $20^{\circ} \mathrm{C} \mathrm{min}{ }^{-1}$ and $130^{\circ} \mathrm{C}$ to $300^{\circ} \mathrm{C}(20 \mathrm{~min})$ at $4^{\circ} \mathrm{C} \min ^{-1}$. The mass spectrometer operated with electron spray ionization at $70 \mathrm{eV}$ and a scan range of $\mathrm{m} / \mathrm{z} 50-650$ with a cycle time of $0.6 \mathrm{~s}$. The interface was set at $300^{\circ} \mathrm{C}$ and the ion source at $200^{\circ} \mathrm{C}$.

Carbon isotopic composition of $n$-alkanes in the apolar fraction and of the GDGT-derived branched alkanes were determined using a ThermoFinnigan DELTA ${ }^{\text {plus } X P \text { Isotope }}$ Ratio Mass Spectrometer (IRMS; electron ionization, $100 \mathrm{eV}$ electron voltage and $1 \mathrm{~mA}$ electron energy; three faraday cup collectors for $m / z, 44,45$ and 46) instrument linked to a Thermo Trace GC via a ThermoFinnigan mark III combustion interface with an oxidation reactor $(\mathrm{Cu}, \mathrm{Ni}, \mathrm{Pt})$ maintained at $940^{\circ} \mathrm{C}$ and a reduction reactor $(\mathrm{Cu})$ at $600^{\circ} \mathrm{C}$. The column and temperature program details were the same as described for the GC-MS with $\mathrm{He}$ as carrier gas. Precision was checked twice a day by running a standard mix of fatty acid methyl esters of known isotopic composition. Based on this, the internal precision of the measurements has been determined to be $\pm 0.3 \%$. All samples were run in duplicate and reported values are means of duplicate measurements. Carbon isotopic values are reported in standard per mill notation $\left({ }^{13} \mathrm{C}\right)$ relative to the Vienna Pee Dee Belemnite (VPDB) international standard.

\subsection{Calculation of turnover time}

The presences of two (natural) labelling experiments in our set of soils allows the calculation of turnover times of branched GDGTs. Full details and references on these calculations can be found in Wiesenberg et al. (2004). In short: after $\mathrm{C}_{4}$-crop introduction on $\mathrm{C}_{3}$-cropped soils, the admixture of the carbon originating from the new $\mathrm{C}_{4}$-vegetation $\left(F_{\text {new }}\right)$ can be calculated as follows:

$F_{\text {new }}=\left(\delta_{\text {new_GDGT }}-\delta_{\text {old_GDGT }}\right) /\left(\delta_{\text {new_plant }}-\delta_{\text {old_plant }}\right)$,

where $\delta_{\text {new_plant }}$ and $\delta_{\text {old }}$ plant are the stable carbon isotopic signatures of $\mathrm{C}_{4}$ - and $\mathrm{C}_{3}$-plants, respectively. $\delta_{\text {new_GDGT }}$ and $\delta_{\text {old_GDGT }}$ are the stable carbon isotopic signatures of the $\mathrm{C}_{4}$-soil-derived branched GDGTs and the original $\mathrm{C}_{3}$-soilderived branched GDGTs, respectively. The residual fraction of $\mathrm{C}_{3}$-derived carbon $\left(F_{\text {old }}\right)$ in the $\mathrm{C}_{4}$-cropped soil can be expressed as:

$F_{\text {old }}=1-F_{\text {new }}$ 
The decay rate or decomposition rate $(k)$ can be calculated as:

$k=\left|\ln \left(F_{\text {old }} / F_{\text {old_t } t}\right) /\left(t-t_{0}\right)\right|$,

with the remaining $F_{\text {old }}$ in the soil at time $t$. Based on this calculation, the turnover time $(T)$, which is used synonymously to the mean residence time (MRT), can be calculated as:

$T=1 / k$.

For the FACE experiment soil, the same formulae are used but instead of a change from a $\mathrm{C}_{3}$-crop to a $\mathrm{C}_{4}$-crop, the difference in carbon isotopic composition of the vegetation is caused by the vegetation growing either under ambient $\mathrm{CO}_{2}$ conditions or under elevated and ${ }^{13} \mathrm{C}$-depleted $\mathrm{CO}_{2}$.

\section{Results and Discussion}

\subsection{GDGT concentrations and distributions}

The complete set of branched (I-IX; Fig. 1) and isoprenoid $(\mathrm{X}-\mathrm{XV})$ GDGTs is present in all soil samples as analyzed by HPLC/MS in selective ion monitoring (SIM) mode. Branched GDGTs are clearly most abundant in the peat sample with a concentration of ca. $290 \mu \mathrm{g} \mathrm{g}^{-1}$ TOC (Table 1). In the soils, concentrations are lower and range from 3 to $84 \mu \mathrm{g} \mathrm{g}^{-1}$ TOC, with the highest concentrations occurring in Rowden grassland. Branched GDGT concentrations in the soils seem to vary irrespective of the type of soil. No systematic difference seems apparent between woodland and grassland, for example; concentrations are not notably higher in the FACE experiment than in other soils, nor are they notably lower in the $\mathrm{C}_{4}$ soils compared to the $\mathrm{C}_{3}$ soils (Table 1).

For the peat as well as the soils, concentrations of the archaeal derived isoprenoid GDGT lipids are generally lower than those of the bacterial derived branched GDGT lipids, consistent with earlier observations (Weijers et al., 2006a, b). Concentrations of the isoprenoid GDGT-0 (X), a common archaeal tetraether membrane lipid, range from less than $0.1 \mu \mathrm{gg}^{-1}$ TOC in the forest soils to $7.2 \mu \mathrm{gg}^{-1}$ TOC in the Rowden grassland soil. In contrast to the branched GDGTs, the concentration of GDGT-0 in the peat, $3.6 \mu \mathrm{g} \mathrm{g}^{-1}$ TOC, is not notably higher than in the soils for this data set. Concentrations of crenarchaeol (XV), most likely derived from soil crenarchaeota (Weijers et al., 2006b), range from $<0.1 \mu \mathrm{g} \mathrm{g}^{-1} \mathrm{TOC}$, i.e. at or below detection limit, in the forest soils, the peat and Rowden grassland soil to $6.9 \mu \mathrm{g} \mathrm{g}^{-1}$ TOC in the FACE soil under elevated $\mathrm{CO}_{2}$. Relatively high concentrations also occur in the FACE control soil and in the Rotthalmünster wheat, maize and grassland soils (Table 1). Notably, these are all soils that received $\mathrm{N}$-fertilization. In general, concentrations of crenarchaeol seem to be higher in soils where branched GDGT concentrations are lower, though some exceptions exist. This observation was made earlier in a larger set of soils and was suggested to be largely governed by soil $\mathrm{pH}$ (Weijers et al., 2006b). In addition, saturation of the soil with water, and thus oxygen availability, might play a role. Branched GDGT and GDGT- 0 concentrations are highest in the water saturated peat sample and in the Rowden grassland soil, which is water saturated large parts of the year, whereas crenarchaeol concentrations in these samples are very low.

\subsection{Alkyl moieties released by ether bond cleavage of GDGTs}

Initially, we performed ether bond cleavage on polar fractions; unfortunately, with the exception of the peat, none of the GDGT-derived alkanes were of sufficient abundance for compound-specific isotopic determinations. One cause of this is that $\mathrm{HI} / \mathrm{LiAlH}_{4}$ treatments of complex mixtures suffer from low yields resulting in such low recovered amounts of released hydrocarbons that IRMS analyses of these render impossible. In addition, GDGT concentrations in soils are low compared to those in peat, i.e. generally one to three orders of magnitude lower (Weijers et al., 2006b, see also Table 1). Released alkanes are therefore easily swamped by other hydrocarbons that might be released by ether bond cleavage of other compounds but most likely are formed via acid-catalysed dehydration reactions of alcohols. Therefore, an additional preparative HPLC purification step was used whereby the GDGT containing solvent extract was cleaned by removing the more apolar and more polar parts of the fraction (see Smittenberg et al., 2002). Although preparative HPLC can also be associated with some loss of material, this step resulted in far simpler chromatograms dominated by putatively GDGT-derived hydrocarbons, most notably 13,16dimethyloctacosane (Fig. 2). However, even after this additional step, carbon isotopic determinations were not possible for all GDGT-derived hydrocarbons.

13,16-Dimethyloctacosane (a in Fig. 1) is generally the most abundant GDGT-derived hydrocarbon released by ether bond cleavage, consistent with GDGT I and II typically being the most abundant core tetraether lipids present. Its $\delta^{13} \mathrm{C}$ value could be determined for all soils (Table 2). 5,13,16Trimethyloctacosane (b) was abundant in almost all samples, but notably not in the Blue Range soil. Presumably because this Australian soil is from a dry and hot environment resulting in low branched GDGT concentrations and a predominance of GDGTs composed of 13,16-dimethyloctacosane (Weijers et al., 2007). GDGTs containing one or two cyclopentyl moieties (c, d) generally are an order of magnitude lower in abundance than GDGTs without cyclopentane moieties. As a consequence, hydrocarbon (c) could only be detected in a few samples, and no carbon isotopic compositions could be determined except for the FACE soil under ambient $\mathrm{CO}_{2}$ conditions. Concentrations of the isoprenoid GDGTs are markedly lower than those of the branched GDGTs, except for the FACE soils, and consequently biphytanes were 
Table 2. Overview of the carbon isotopic composition (with standard deviation) of TOC, plant wax-derived odd-numbered $n$-alkanes and the different alkyl moieties released from the GDGTs by ether bond cleavage. The bold letters refer to the structures of the carbon chains drawn in Fig. 1.

\begin{tabular}{|c|c|c|c|c|c|c|c|c|c|c|c|c|c|}
\hline \multicolumn{14}{|c|}{$\delta^{13} \mathrm{C}(\% \circ$ vs. VPDB $)$} \\
\hline & TOC & $n-\mathrm{C}_{27}$ & $n-\mathrm{C}_{29}$ & $n-\mathrm{C}_{31}$ & $n-\mathrm{C}_{33}$ & $\mathbf{a}$ & b & $\mathbf{c}$ & d & e & f & $\mathbf{g}$ & $\mathbf{h}$ \\
\hline \multicolumn{14}{|l|}{ Forest soil } \\
\hline Leigh Woods & -27.9 & $-33.9(0.1)$ & $-34.7(0.1)$ & $-35.6(0.7)$ & $-35.6(0.1)$ & $-28.5(0.1)$ & $-28.1(0.8)$ & b.d. & b.d. & b.d. & b.d. & b.d. & b.d. \\
\hline Rotthalmünster & $-25.7^{\mathrm{c}}$ & $-34.0(0.7)$ & $-36.6(0.4)$ & $-36.2(0.0)$ & $-38.2(0.6)$ & $-27.5(0.1)$ & $-27.4(0.5)$ & b.d. & b.d. & b.d. & b.d. & b.d. & b.d. \\
\hline \multicolumn{14}{|l|}{ Grassland soil } \\
\hline Rotthalmünster & $-28.0^{\mathrm{c}}$ & $-36.7(0.2)$ & $-36.8(0.3)$ & $-37,4(0.0)$ & $-38.0(0.4)$ & $-29.2(1.6)$ & $-28.8(1.8)$ & b.d. & b.d. & b.d. & b.d. & $-29.3(0.4)$ & $-29.5(0.7)$ \\
\hline Rowden I & -29.3 & $-37.0(0.4)$ & $-37.6(1.9)$ & $-37.0(1.6)$ & $-37.3(2.1)$ & $-30.1(1.0)$ & $-29.0(0.1)$ & b.d. & b.d. & $-33.4(0.8)$ & b.d. & b.d. & b.d. \\
\hline Rowden II & -27.9 & $-35.0(0.3)$ & $-34.4(0.4)$ & $-34.6(0.4)$ & $-34.4(0.1)$ & $-30.5(0.4)$ & $-30.1(0.7)$ & b.d. & b.d. & -32.0 (n.d.) & b.d. & b.d. & b.d. \\
\hline Rowden III & -27.0 & b.d. & $-33.3(0.5)$ & $-34.4(0.4)$ & $-34.8(0.8)$ & $-30.0(0.1)$ & $-29.7(0.6)$ & b.d. & b.d. & b.d. & b.d. & b.d. & b.d. \\
\hline \multicolumn{14}{|l|}{ Cropland soil } \\
\hline Rotthalmünster wheat & $-26.6^{\mathrm{c}}$ & $-36.8(1.8)$ & $-38.8(0.2)$ & $-38.1(0.1)$ & $-39.5(0.1)$ & $-26.9(0.1)$ & $-26.7(1.0)$ & b.d. & b.d. & $-29.4(0.6)$ & b.d. & b.d. & $-29.1(0.6)$ \\
\hline \multicolumn{14}{|l|}{ Peat soil } \\
\hline Stordalen mire & -23.8 & $-36.6(1.7)$ & $-33.7(1.2)$ & $-32.7(0.1)$ & $-33.5(0.1)$ & $-29.1(0.0)$ & $-28.7(0.0)$ & b.d. & b.d. & $-29.7(0.2)$ & b.d. & b.d. & b.d. \\
\hline Bargerveen ${ }^{a}$ & -27.5 & $-31.0(0.4)$ & $-31.0(0.4)$ & $-31.5(0.4)$ & $-31.5(0.4)$ & $-26 /-30.5$ (n.d.) & n.d. & b.d. & b.d. & $-25 /-29(1.0)$ & $-34.5 /-36.5(1.0)$ & b.d. & b.d. \\
\hline \multicolumn{14}{|l|}{ FACE soil } \\
\hline T. repens ambient $\mathrm{CO}_{2}$ & $-26.8^{\mathrm{d}}$ & $-36.3(0.3)$ & $-36.5(0.0)$ & $-36.9(0.3)$ & $-36.7(0.0)$ & $-27.1(0.1)$ & b.d. & $-29.1(0.8)$ & b.d. & $-28.6(0.4)$ & b.d. & $-28.0(1.4)$ & $-28.8(1.8)$ \\
\hline T. repens elevated $\mathrm{CO}_{2}^{\mathrm{b}}$ & $-29.8^{\mathrm{d}}$ & $-39.0(0.1)$ & $-38.7(0.4)$ & $-38.3(0.4)$ & $-3.7(0.8)$ & $-31.3(0.8)$ & b.d. & b.d. & b.d. & -29.2 (n.d.) & b.d. & b.d. & $-30.4(0.9)$ \\
\hline \multicolumn{14}{|l|}{$\mathrm{C}_{4}$ vegetated soil } \\
\hline Blue Range & $-17.0^{\mathrm{e}}$ & & b.d. & $-23.9(2.0)$ & $-22.7(1.8)$ & $-18.0(1.5)$ & b.d. & b.d. & b.d. & b.d. & b.d. & b.d. & b.d. \\
\hline Rotthalmünster maize & $-21.3^{\mathrm{c}}$ & $-29.2(0.2)$ & $-31.9(0.6)$ & $-31.6(0.5)$ & $-31.8(0.4)$ & $-18.8(0.8)$ & b.d. & b.d. & b.d. & b.d. & b.d. & b.d. & $-23.0(1.4)$ \\
\hline
\end{tabular}

a all data from Pancost and Sinninghe Damsté (2003) and Pancost et al. (2003)

${ }^{b}$ note that the $\mathrm{CO}_{2}$ used for the FACE experiment (during day time only) was depleted in $\delta^{13} \mathrm{C}$ by $10 \%$ relative to atmospheric $\mathrm{CO}_{2}$

${ }^{\mathrm{c}}$ data from John et al. (2005)

$\mathrm{d}$ data from Wiesenberg et al. (2008)

e data from Krull and Bray (2005)

b.d. $=$ below detection limit or co-elution that prevents carbon isotope determination

n.d. $=$ not determined
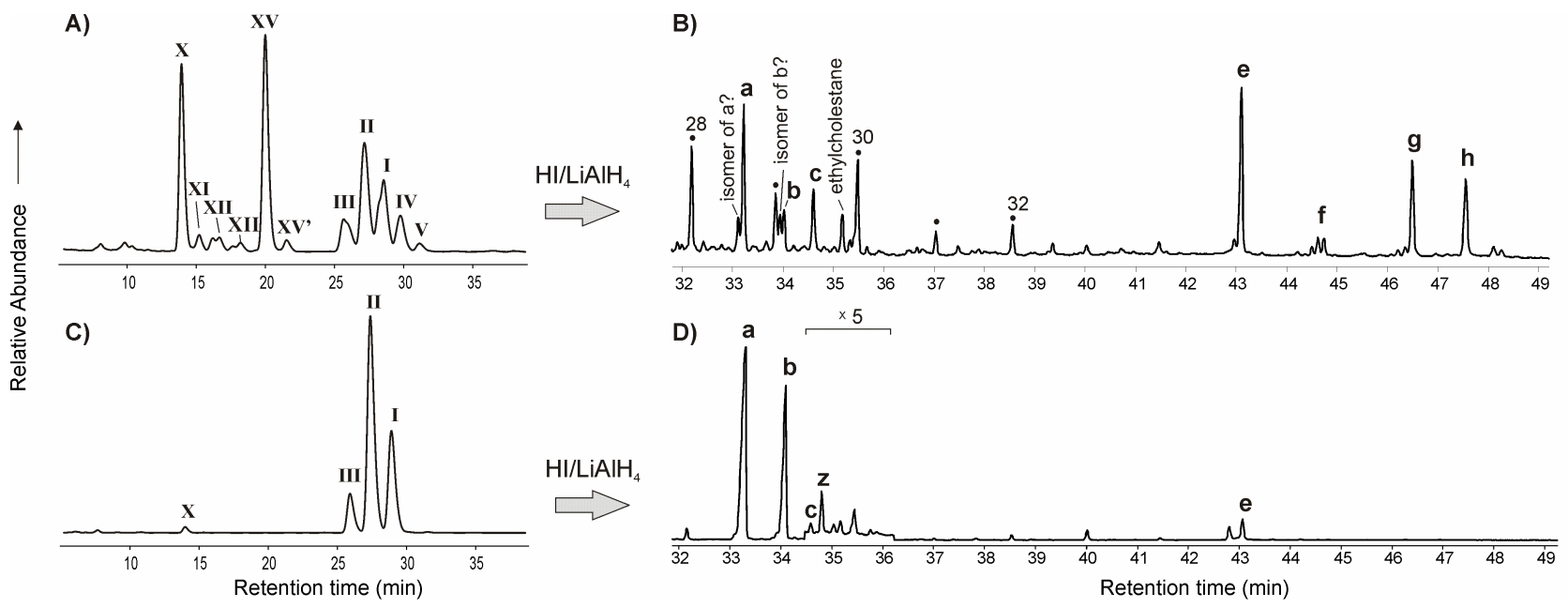

Fig. 2. Partial LC and GC chromatograms of the FACE soil under ambient $\mathrm{CO}_{2}$ conditions (A and $\mathbf{B}$, respectively) and of the Stordalen mire peat ( $\mathbf{C}$ and $\mathbf{D}$, respectively). The polar fraction of the total extracts, containing the GDGT compounds (roman numerals in A and $\mathbf{C}$, numbers refer to Fig. 1), has been enriched in GDGTs by means of preparative HPLC. Subsequently, the alkyl moieties have been released by cleaving the ether bonds with an $\mathrm{HI} / \mathrm{LiAlH}_{4}$ treatment. The GC chromatograms shown in B and D represent the hydrocarbon fraction obtained from the respective samples after this treatment. Letters $\mathbf{a}-\mathbf{h}$ refer to the structures in Fig. 1. Bullets represent $n$-alkane series with corresponding chain length that most likely derive from dehydration of higher plant derived $n$-alkanols and subsequent reduction of the double bond by $\mathrm{LiAlH}_{4}$. The peaks eluting just before peak a and $\mathrm{b}$ have the exact same mass spectrum and are therefore suggested to be stereoisomers of a and $b$, respectively. The peak indicated wit $\mathbf{z}$ in panel $\mathrm{D}$ is tentatively identified as 5,13,16,24-tetramethyloctacosane, see Fig. 3 . Note that the vertical scale in panel D is magnified 5 times between 34.5 and $36.5 \mathrm{~min}$. 


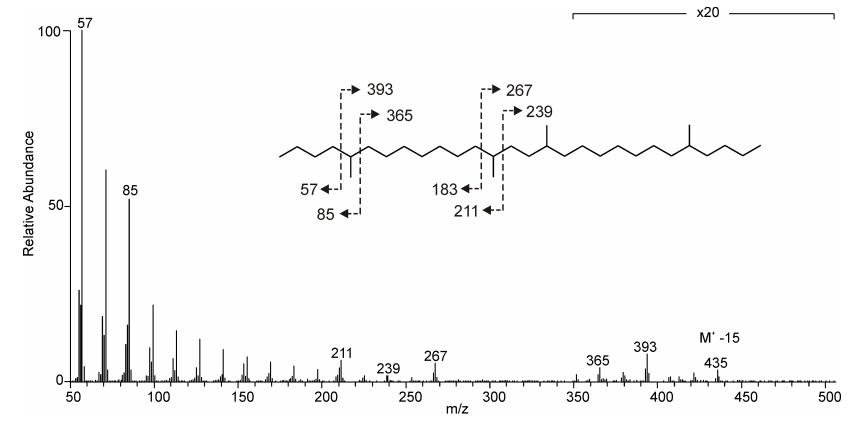

Fig. 3. Mass spectrum (electron spray ionisation) of compound " $\mathrm{z}$ " from Stordalen mire (Fig. 2d) with the structure tentatively identified as 5,13,16,24-tetramethyloctacosane. The mass spectrum has been corrected for background. Note that the vertical scale is magnified by a factor 20 from $\mathrm{m} / \mathrm{z} 350$ onward.

not detected in all soils. The acyclic biphytane (e in Fig. 1) was obtained by ether bond cleavage of GDGTs in most of the soils, although often in trace amounts preventing determination of its carbon isotopic composition in some of the soils. The tricyclic biphytane containing a cyclo-hexane moiety (h), released from crenarchaeol (XV) and its regioisomer, could only be detected in some samples of which 5 had sufficient abundances for $\delta^{13} \mathrm{C}$ analysis. The mono- and dicyclic biphytanes (f) and (g) were generally low in abundance and only for two samples amounts of the dicyclic biphytane (g) were sufficient for $\delta^{13} \mathrm{C}$ analysis.

In the $\mathrm{HI} / \mathrm{LiAlH}_{4}$ treated fraction of the Stordalen mire peat, an unknown compound was observed eluting at 34.8 min ( $\mathrm{z}$ in Fig. 2d), right in sequence behind 13,16dimethyloctacosane (a) and 5,13,16-trimethyloctacosane (b), respectively and thus possibly a tetramethyloctacosane. The molecular ion is $m / z 450$, based on the $\left[\mathbf{M}^{+}-15\right]$ ion being $m / z, 435$, consistent with this being a $\mathrm{C}_{32} \mathrm{H}_{66}$ hydrocarbon. The mass spectrum of compound $\mathrm{z}$ (Fig. 3) shows elevated peaks at $\mathrm{m} / z 211$ and 267, similar to the fragmentation pattern of the 5,13,16-trimethyloctacosane, but also shows elevated peaks at $m / z 365$ and 393 which is consistent with the presence of a 4th methyl group at the C-24 position. In addition, the calculated Kovats Retention Index (RI) of 2961 for the peak representing compound $\mathrm{z}$ is similar to the theoretical RI of 2960 for 5,13,16,24-tetramethyloctacosane calculated based on the additivity principle (Kissin et al., 1986). Therefore, compound $\mathrm{z}$ is tentatively identified as 5,13,16,24tetramethyloctacosane (Fig. 3). This suggests that GDGT $\mathrm{m} / \mathrm{z} 1050$ (III) could not only be composed of two 5,13,16trimethyloctacosanyl moieties (Fig. 1), but also of a combination of a 13,16-dimethyloctacosanyl and a 5,13,16,24tetramethyloctacosanyl moiety. If these isomers exist, this might explain the fact that in HPLC-MS chromatograms, the peak representing GDGT III in the $\mathrm{m} / \mathrm{z} 1050$ mass chromatogram is often broader and more irregularly shaped than observed for the peaks representing GDGTs I and II. This should, however, be confirmed by additional analyses. The preliminary identification of compound $\mathrm{z}$ also suggests that GDGTs with $m / z, 1064$ and $m / z, 1078$ could exist, i.e. with a combination of tri- and tetra-methylated, or two tetramethylated carbon moieties, respectively. However, these compounds have so far not been reported, although the SIM approaches often used in GDGT analyses, especially of ancient sediments, would not have detected such components. A screening with HPLC-MS of several peat samples for these compounds did not reveal clear signals that reached above background levels. Together with compound $\mathrm{z}$ being rather small relative to $a$ and $b$ in the Stordal mire peat (Fig. 2d), this suggests that they are far less common.

\subsection{Stable carbon isotopic compositions}

The isotopic composition of bulk organic carbon ranges from -25.7 to $-29.3 \%$ o for soils under $\mathrm{C}_{3}$ type vegetation (Table 2), consistent with a $\mathrm{C}_{3}$ vegetation source (Boutton et al., 1998 and references therein). The $\delta^{13} \mathrm{C}_{\mathrm{TOC}}$ of the FACE soil kept under elevated $\mathrm{CO}_{2}$ conditions is depleted $(-29.8 \%$ ), relative to the control soil under ambient $\mathrm{CO}_{2}$ conditions, due to the use of ${ }^{13} \mathrm{C}$-depleted $\mathrm{CO}_{2}$ for fumigation. Bulk organic carbon $\delta^{13} \mathrm{C}$ values are -17 to $-21.3 \%$ of the two soils under $\mathrm{C}_{4}$ type vegetation, consistent with a significant $\mathrm{C}_{4}$ vegetation input (Boutton et al., 1998 and references therein). However, the $\delta^{13} \mathrm{C}_{\mathrm{TOC}}$ of the Rotthalmünster maize soil is somewhat lower than that of the Australian $\mathrm{C}_{4}$ soil, likely reflecting the presence of a pool of recalcitrant carbon that is older than 23 years and derived from the $\mathrm{C}_{3}$ vegetation that was present before the change to maize cultivation.

Plant leaf wax $n$-alkanes were present in all soils, with $n-\mathrm{C}_{31}$ typically being the most abundant. Their $\delta^{13} \mathrm{C}$ values typically vary between -34 and $-39 \%$ o for the $C_{3}$ soils, with generally the lower values for the longer $n$-alkanes (Table 2). In the Rowden grassland, where a shallow depth profile has been sampled, $\delta^{13} \mathrm{C}$ values of both TOC and the $n$ alkanes increase slightly with depth, an observation that has been previously made and for which potential explanations include increasing biodegradation and incorporation of microbial biomass with depth (and time) and, though small, the Suess effect, i.e. the decrease in $\delta^{13} \mathrm{C}$ values of atmospheric $\mathrm{CO}_{2}$ over the last 200 years (Huang et al., 1996; Ehleringer et al., 2000 and references therein; Bostrom et al., 2007). Also, carbon input via root biomass and root exudates into the deeper soil layers might have an important, though not yet well investigated, effect on carbon isotopic compositions along a soil profile (e.g. Wiesenberg et al., 2010). The $\delta^{13} \mathrm{C}$ value of $n$-alkanes in the Stordalen mire is higher than in soils but comparable to values reported for the Bargerveen bog (-31.5\%o, Pancost and Sinninghe Damsté, 2003) and other peats (e.g. Xie et al., 2004). The carbon isotopic composition of $n$-alkanes in the FACE soil kept 10 years under elevated $\mathrm{CO}_{2}$ conditions is, like the TOC, depleted relative to the control soil kept under ambient $\mathrm{CO}_{2}$ conditions, resulting 
from the fact that $\mathrm{CO}_{2}$ above the enriched plot was $10 \%$ o depleted in ${ }^{13} \mathrm{C}$ relative to atmospheric $\mathrm{CO}_{2}$. This is in line with earlier results for the same soils obtained by Wiesenberg et al. (2008), although they acknowledge that the difference vary strongly among individual $n$-alkanes. The carbon isotopic compositions of the $n$-alkanes in $\mathrm{C}_{4}$ soils, like those of the TOC, are clearly higher than in $\mathrm{C}_{3}$ soils. This is especially true for the Blue Range soil, whereas values for the maize soil are somewhere intermediate between typical $\mathrm{C}_{3}$ and $\mathrm{C}_{4} n$-alkane $\delta^{13} \mathrm{C}$ values $(-36$ and $-21 \%$ o, repectively, Collister et al., 1994). This is related to the presence of a large proportion $(60 \%)$ of old ( $>23 \mathrm{yr}$ ) and recalcitrant $\mathrm{C}_{3}$ plant derived $n$-alkanes in the Rotthalmünster maize cropped soil (Wiesenberg et al., 2004).

The $\delta^{13} \mathrm{C}$ values of the branched GDGT-derived alkanes (a) and (b) from the $\mathrm{C}_{3}$ vegetated soils vary between -26.7 and $-30.1 \%$ (Table 2); values for trimethyloctacosane (b) are enriched by ca. $0.3 \%$ relative to dimethyloctacosane (a), however, this is within the analytical error. In general, these values are clearly higher than the plant wax lipids but slightly lower $(0.6 \%$ on average) than the carbon isotopic composition of TOC. Moreover, within a given soil type, branched GDGT-derived alkane $\delta^{13} \mathrm{C}$ values exhibit less variability than those of $n$-alkanes. For example, GDGT-derived alkane $\delta^{13} \mathrm{C}$ values exhibit no depth-dependant variation in the Rowden grassland soil, with values constant around $-30 \%$ o. For the FACE soil kept under elevated (and ${ }^{13} \mathrm{C}$-depleted) $\mathrm{CO}_{2}$, a depletion is observed for the GDGT-derived hydrocarbons relative to the control soil under ambient $\mathrm{CO}_{2}$ conditions (ca. $-4 \%$ ), which is slightly larger than that observed for TOC $(-3 \%)$, and certainly larger than that observed for the long chain $n$-alkanes (ca. $-2 \%$; Table 2). The $\delta^{13} \mathrm{C}$ values for dimethyloctacosane in the $\mathrm{C}_{4}$ soils are between -18 and $-19 \%$. These values are clearly higher than values found in $\mathrm{C}_{3}$ soils. Strikingly, and in contrast to the TOC and $n$-alkanes, the carbon isotopic composition of GDGTderived alkanes in the maize soil are similar to those in the Blue Range soil (cf., ca. $-1 \%$ o for dimethyloctacosane, ca. $-4 \%$ ofor TOC and ca. $-8 \%$ o for the $n$-alkanes; Table 2 ).

The FACE soil under ambient $\mathrm{CO}_{2}$ conditions was the only soil for which a carbon isotopic composition could be determined for 1-(3'-methylpentadecyl)-4-nonylcyclopentane (c), i.e. the dimehtyloctacosane in which one methyl group has formed a pentacyclic moiety by internal cyclisation to a $\delta$ carbon (Weijers et al., 2006a). This value is slightly lower than those of the acyclic component (a), $-29.1 \%$ as opposed to $-27.1 \%$. We have, however, insufficient data to examine whether or not this is a typical characteristic.

Carbon isotopic values for the acyclic biphytane (e), derived mainly from GDGT X, could be determined for half of the soils (Table 2). The $\delta^{13} \mathrm{C}$ values range from $-28.6 \%$ o to $-33.4 \%$ and are generally depleted by 2 to $3 \%$ relative to the branched GDGT-derived alkanes, with the exceptions being the peat and the FACE soil kept under elevated and ${ }^{13} \mathrm{C}$ depleted $\mathrm{CO}_{2}$. Carbon isotopic compositions of the tricyclic biphytane (h), derived from crenarchaeol (GDGT XV), could be determined for five soils and are -29.5 to $-28.8 \%$ in the $\mathrm{C}_{3}$ soils and $-23 \%$ in the $\mathrm{C}_{4}$ maize soil (Table 2). Notably, in the FACE control soil, the dicyclic biphytane (g) is also largely derived from crenarchaeol. This is evident from the fact that the monocyclic biphytane (f), derived from GDGTs XI-XIII and not sourced by crenarchaeol, is only just above detection limit (Fig. 2b). The $\delta^{13} \mathrm{C}$ value of the dicyclic biphytane ( $\mathrm{g}$ ) in this soil is $-28.0 \%$ and thus closely resembles that of the tricyclic biphytane (h). It has to be noted, though, that crenarchaeol derived biphytane peaks were generally small and that their $\delta^{13} \mathrm{C}$ values are associated with slightly larger errors, on average $\pm 1.1 \%$.

\subsection{The metabolism of isoprenoid GDGT producers}

16S rRNA gene sequence analyses have proven the presence of group I.1b Crenarchaeota in soils (e.g. Bintrim et al., 1997; Leininger et al., 2006), and their specific biomarker lipid crenarchaeol has also been widely reported in soils (e.g. Leininger et al., 2006; Weijers et al., 2006b, XV in Fig. 2a). Therefore, soil Crenarchaeota are almost certainly the source of the tricyclic biphytane (h) (Fig. 1). The metabolic strategy of soil crenarchaeota is similar to the marine pelagic Crenarchaeota, i.e., nitrifiers oxidising ammonium to nitrite (e.g. Leininger et al., 2006). This similar strategy might also explain the relatively high concentrations of crenarchaeol (XV) in the fertilized soils and especially in the FACE soils under $T$. repens vegetation $(2-7 \mu \mathrm{g} / \mathrm{gTOC}$, Table 1). Legumes, like clover, are known to symbiotically fix atmospheric nitrogen into the soil (e.g. Abberton et al., 1999), which might intensify the N-cycle and thus the presence of Crenarchaeota in the soil. The crenarchaeol-derived biphytane (h) $\delta^{13} \mathrm{C}$ values, despite their relatively larger errors, are among the first measurements of any kind of soil crenarchaeotal biomass. The values are lower than those of TOC $\delta^{13} \mathrm{C}$ by 1.5 to $2.5 \%$ and slightly lower than those of the branched GDGT-derived alkanes. The $\delta^{13} \mathrm{C}$ values for biphytane (h) in the $\mathrm{C}_{3}$ soils ( -28.8 to $-29.5 \%$, see Table 2 ) are considerably lower than values reported for marine crenarchaeol, which vary between -20 and $-22 \%$ o (e.g. Hoefs et al., 1997; Schouten et al., 1998; Wakeham et al., 2003; Pancost et al., 2008). These marine crenarchaeol values are relatively high because marine Crenarchaeota are chemoautotrophic organisms assimilating $\mathrm{CO}_{2}$ and $\mathrm{HCO}_{3}^{-}$via a modified 3-hydroxypropionate pathway (e.g., Kuypers et al., 2001; Wuchter et al., 2003; Berg et al., 2007). Given the similar metabolic strategy for soil Crenarchaeota, it will be soil $\mathrm{CO}_{2}$ that is used by these Crenarchaeota as their primary carbon source. Evidence for this comes from a study by Urich et al. (2008), who showed the presence of soilCrenarchaeotal gene products diagnostic for a $\mathrm{CO}_{2}$ fixation pathway based on a RNA centered meta-transcriptomic analysis of a nutrient-poor sandy lawn soil from Germany. Since in active soils soil $\mathrm{CO}_{2}$ is dominantly derived from soil 
organic matter via respiration, this explains the depleted values relative to marine crenarchaeol.

The acyclic $\mathrm{C}_{40}$ isoprenoid biphytane (e) could derive from either methanogenic archaea, which dominantly synthesise the acyclic dibiphytane tetraether GDGT-0 (X) and smaller amounts of GDGT-1 (XI) (reviewed in Kates et al., 1993), or soil crenarchaeota who synthesise similar GDGTs in addition to crenarchaeol (XV) (Sinninghe Damsté et al., 2002; Weijers et al., 2006b). Other uncultivated or unknown Euryarchaeota, however, cannot be completely excluded here as a potential source. The $\delta^{13} \mathrm{C}$ values of the acyclic biphytanes vary between $-28.6 \%$ and $-33.4 \%$ (Table 2 ).

In group I Crenarchaeota, the ratio of GDGT X to XV is temperature dependent and generally varies between 0.2 and 2 (Schouten et al., 2002). Given the relative distributions of GDGT X and XV in the soils (Table 1), it is mainly in the Rowden soil and the Stordalen mire that a near exclusive methanogenic source is to be expected without crenarchaeotal admixture (i.e. very high ratios of GDGT $\mathrm{X}$ relative to $\mathrm{XV}$ ). Carbon isotopic compositions of the acyclic biphytanes (e) in the Rowden soil and the Stordalen mire are indeed lower and more depleted in ${ }^{13} \mathrm{C}$ relative to TOC than the same compounds in soils where a larger contribution from Crenarchaeota is expected, i.e. the Rotthalmünster wheat soil and the FACE soils (GDGT X/XV ratio of $0.28,0.77$ and 0.71 , respectively). In fact, in these latter soils the $\delta^{13} \mathrm{C}$ values of biphytanes (e) and (h) are rather similar, suggesting a similar source, i.e. soil Crenarchaeota.

The carbon isotopic composition of $-28 \%$ for the acyclic biphytanes reported in Bargerveen bog were suggested to reflect methanogenic archaea using acetate as a substrate, as opposed to autotrophic methanogens utilising $\mathrm{CO}_{2} / \mathrm{H}_{2}$ (Pancost et al., 2000; Pancost and Sinninghe Damsté, 2003). This was because the latter are expected to be considerably depleted in ${ }^{13} \mathrm{C}$ (Summons et al., 1998). Here, we see similar $\delta^{13} \mathrm{C}$ values for biphytane (e) in the Stordalen mire sample and only slightly lower values in the Rowden grassland soil, suggesting that in these soils a considerable amount of the methanogens are also heterotrophic using acetate to produce $\mathrm{CH}_{4}$. The ubiquity of this observation is consistent with a dominantly acetotrophic metabolism across a range of terrestrial environments (Whiticar et al., 1986).

\subsection{The metabolism of branched GDGT producers}

The carbon isotopic compositions of branched GDGTderived alkanes ( $a$ and $b$ ) generally track those of the $\delta^{13} \mathrm{C}_{\mathrm{TOC}}$. For the $\mathrm{C}_{3}$ top soils, (a) and (b) are, on average, depleted by $0.6 \%$ relative to TOC. Only the Rotthalmünster maize cropped soil shows a different pattern, i.e. an enrichment of the dimethyl octacosane relative to TOC by $2.5 \%$. The similarity of TOC and bacterial lipid $\delta^{13} \mathrm{C}$ values is consistent with a heterotrophic metabolism for branched-GDGT synthesising bacteria (Fig. 4). Little fractionation occurs during bacterial heterotrophy, i.e. during conversion from plant to bacterial biomass (Hayes, 1993). However, it is not biomass but membrane lipids that have been analysed here, and isotopic fractionation during lipid biosynthesis does occur (DeNiro and Epstein, 1977). This fractionation depends on substrate, synthetic pathway and growth conditions and generally ranges anywhere between -2 to $-8 \%$ o (e.g. DeNiro and Epstein, 1977; Hayes, 1993; 2001), but could be larger (Teece et al., 1999; e.g. Schouten et al., 2004) or even reversed, i.e. enriched relative to biomass (e.g. van der Meer et al., 1998). Except for organisms using the reversed tricarboxylic acid cycle (van der Meer et al., 1998), however, fatty acids and other acetogenic (straight chain) lipids are expected to be ca. 4\%o depleted relative to biomass (Hayes, 1993), and lipid fractionation associated with anaerobic bacteria is often observed to be larger than this 4\%o (e.g. Teece et al., 1999; Zhang et al., 2003). Thus, if heterotrophs are consuming bulk organic matter, we would expect the bacterial lipids to not only track TOC $\delta^{13} \mathrm{C}$ values but also to be depleted by 2 to $8 \%$ relative to TOC $\delta^{13} \mathrm{C}$ values. The fact that this is not observed suggests that the heterotrophic bacteria are preferentially consuming a ${ }^{13} \mathrm{C}$-enriched component of the TOC pool. These could be carbohydrates and/or proteins, as these are generally quickly assimilated by microbes (e.g. Berggren et al., 2010) and about $0-9 \%$ enriched in ${ }^{13} \mathrm{C}$ relative to bulk tissue (e.g. Abelson and Hoering, 1961; van der Meer et al., 2001; van Dongen et al., 2002; Copley et al., 2003). A similar theory for heterotrophy, i.e. consuming ${ }^{13} \mathrm{C}$ enriched components of the TOC pool, has been proposed by Huang et al. (1996) for the source of bacterial hopenes in soil and peat. They found that hop-22(29)-enes and neohop-13(18)-enes in soil and peat were only slightly depleted in ${ }^{13} \mathrm{C}$ (ca. $2 \%$ ) relative to TOC, but 4-5\%o enriched relative to plant derived $n$ alkanes. Support for the use of more labile substrates, such as carbohydrates, comes from the Rowden grassland depth profile, where branched GDGT-derived alkane $\delta^{13} \mathrm{C}$ values do not increase with depth, as is the case for TOC, $n$-alkane and GDGT- 0 derived biphytane $\delta^{13} \mathrm{C}$ values. This suggests that the branched GDGT-synthesising bacteria feed on a readily available and continuously replenished food source, rather than the stock of OM that tends to get enriched in ${ }^{13} \mathrm{C}$ with depth in this soil. If labile components are present at depth, it is most likely that they are either derived from the surface, possibly transported as dissolved organic carbon, or derived from root exudates, which contain large amounts of low molecular weight compounds like carbohydrates, carboxylic acids and amino acids (e.g. Gransee and Wittenmayer, 2000).

Pancost and Sinninghe Damsté (2003) similarly suggested a heterotrophic life style for the branched-GDGT synthesising organism in the Bargerveen peat bog based on similar small differences between the isotopic compositions of 13,16-dimethyloctacosane and TOC. Supporting evidence arose from the fact that a stratigraphic shift in $\delta^{13} \mathrm{C}$ values of 13,16-dimethyloctacosane in the peat profile corresponded to similar $\delta^{13} \mathrm{C}$ shifts in TOC and hopanes derived from heterotrophic bacteria. Also Oppermann et al. (2010) recently 


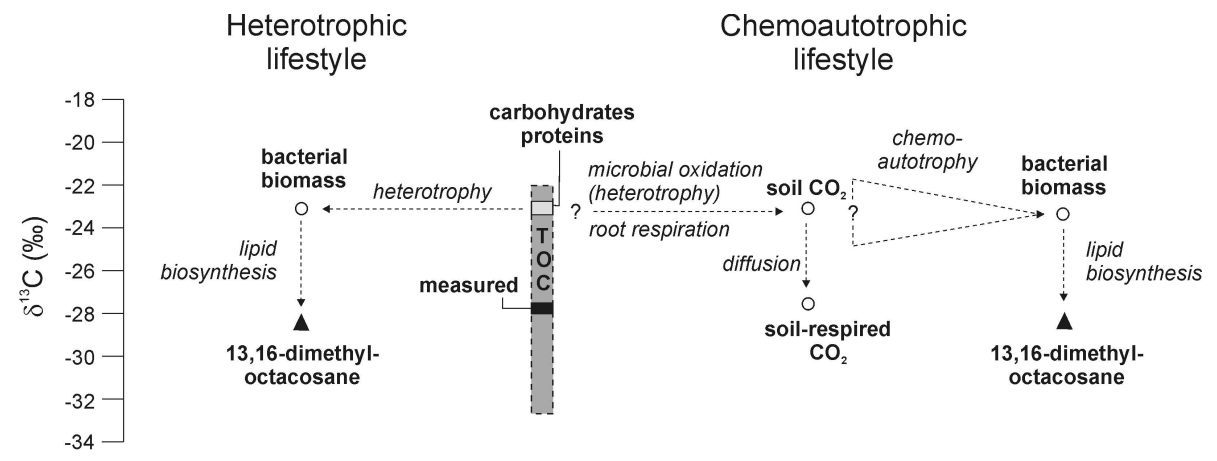

Fig. 4. Simplified schematic representation of the potential heterotrophic metabolism (left hand side) and chemoautotrophic metabolism (right hand side) of the branched GDGT-synthesising bacteria. Filled symbols represent averages of measured values (for the $\mathrm{C}_{3}$ top-soils), open symbols represent estimated values based on fractionation factors from the literature.

suggested a heterotrophic metabolism for branched GDGTsynthesising organisms. They compared the stable carbon isotopic composition of microbial lipids in a soil on a $\mathrm{CO}_{2}$ vent, receiving naturally labelled $\mathrm{CO}_{2}$, to a nearby reference soil away from this vent. Similar small differences between TOC and branched GDGT-derived alkane $\delta^{13} \mathrm{C}$ values in the two soils were observed. By expanding this relationship to a range of $\mathrm{C}_{3}$ and $\mathrm{C}_{4}$ vegetated soils, our work reinforces this hypothesis, i.e. that bacterial GDGT-producers have a heterotrophic life style.

Based on the $\delta^{13} \mathrm{C}$ value of GDGT lipids alone, however, it cannot be excluded that the GDGT-producing bacteria are chemoautotrophic organisms assimilating $\mathrm{CO}_{2}$. If so, the relationship between TOC and GDGT-derived alkane $\delta^{13} \mathrm{C}$ values arises because the isotopic composition of organic matter is an important control on soil $\mathrm{CO}_{2} \delta^{13} \mathrm{C}$ values, i.e. the substrate material, being decaying organic matter, is ultimately the same (e.g. Kuzyakov, 2006 and references therein). It is important to note here that soil $\mathrm{CO}_{2}$ present in the soil and respired $\mathrm{CO}_{2}$ emitted from a soil (and often being the one that is measured) are not isotopically the same. Generally, soil $\mathrm{CO}_{2}$ is enriched in ${ }^{13} \mathrm{C}$ relative to $\mathrm{CO}_{2}$ respired from the soil due to the difference in diffusion coefficients for ${ }^{12} \mathrm{CO}_{2}$ and ${ }^{13} \mathrm{CO}_{2}$ (Cerling et al., 1991). Based on theory and observation this difference is about 4.4\%o (Cerling et al., 1991). Theoretically, branched GDGT-synthesising bacteria might use any $\mathrm{CO}_{2}$ along this diffusive gradient. However, the $\delta^{13} \mathrm{C}$ value of $\mathrm{CO}_{2}$ emitted from soils roughly equals that of the (fresh) soil organic matter (e.g. Crow et al., 2006). Because the $\delta^{13} \mathrm{C}$ values of branched GDGT-derived alkanes equals the $\delta^{13} \mathrm{C}$ of TOC, and accounting for fractionation associated with lipid biosynthesis (which will likely be of the same order as the $4.4 \%$ difference between soil $\mathrm{CO}_{2}$ and soil-respired $\mathrm{CO}_{2}$ ), it seems that the microorganisms, if autotrophic, would have to consume the soil $\mathrm{CO}_{2}$ (Fig. 4).

To explore this further, we can compare the $\delta^{13} \mathrm{C}$ values of dimethyloctacosane with those of biphytanes derived from crenarchaeol and thus, from an unambiguous chemoautotroph (see Sect. 4.4). Crenarchaeol derived biphytanes (h), are slightly depleted relative to branched GDGT-derived alkanes (a) for all soils in which both could be measured, except the FACE soil under elevated $\mathrm{CO}_{2}$ conditions (Table 2). Although these differences, given the associated errors, are not large and consistent with a potential chemoautotrophic metabolism for the branched GDGT-synthesising organisms, it has to be noted that differences in fractionation during biosynthesis of straight chain or isoprenoid lipids could be large, depending on the carbon assimilation pathway (e.g. van der Meer et al., 1998), thus hindering such a direct comparison of $\delta^{13} \mathrm{C}$ values. Oppermann et al. (2010) presented data that circumvent this problem. They compared the difference in $\delta^{13} \mathrm{C}$ values of branched GDGT-derived alkanes between a reference soil and a soil on a $\mathrm{CO}_{2}$ vent site with the difference in $\delta^{13} \mathrm{C}$ values of biphytanes derived from presumably autotrophic methanogens for the same sites. The change in $\delta^{13} \mathrm{C}$ of the branched GDGT-derived alkanes between the $\mathrm{CO}_{2}$ vent site and the reference site (ca. 5\%o) was not as large as the change for the methanogen-derived biphytanes (ca. 18\%o), which suggested that branched-GDGT synthesising bacteria do not feed directly on the $\mathrm{CO}_{2}$. The authors do acknowledge, however, that it was not possible to determine to what extent heterotrophic methanogens contribute to the $\mathrm{C}_{40}$ biphytanes at the reference site, which might account for part of the observed difference.

Nevertheless, the balance of evidence (i.e. the $\delta^{13} \mathrm{C}$ values of branched GDGTs being similar to, and tracking that, of TOC; a similar stratigraphic shift as heterotrophs in a peat bog (Pancost and Sinninghe Damsté, 2003); and seemingly not incorporating the signal of naturally labelled $\mathrm{CO}_{2}$ from a vent system (Oppermann et al., 2010) strongly suggests that branched GDGT-producing bacteria are heterotrophic organisms rather than chemoautotrophic organisms. The high concentrations of branched GDGTs in the anaerobic horizons of peat and their predominance over other GDGT lipids, including those derived from methanogenic archaea (Weijers et al., 2006a, 2009), suggest that branched GDGT-synthesising organisms are similarly predominant. Given this, as well as their putative heterotrophic lifestyle, they are potentially 
associated with the terminal processes in organic matter degradation, i.e. the fermentation of labile organic matter, and could generate substrates for other anaerobic organisms such as methanogens. Of course, these issues remain unresolved, but until the branched GDGT-synthesising bacteria have been identified and cultured, stable isotope pulse labelling experiments, for example using glucose or $\mathrm{CO}_{2}$, could potentially provide additional insight into the mechanisms of carbon assimilation.

\subsection{GDGT turnover time}

Amongst the soils analysed, two experienced a dramatic change in the isotopic composition of their vegetation cover over the past decades, and this can be used to evaluate the turnover time of GDGTs in soil. The first is the switch from a $\mathrm{C}_{3}$ crop to maize $\left(\mathrm{C}_{4}\right)$ cultivation for the Rotthalmünster maize soil 23 years ago; the second is the free-air $\mathrm{CO}_{2}$ enrichment study, in which the plants were fumigated with elevated levels of ${ }^{13} \mathrm{C}$-depleted $\mathrm{CO}_{2}$ for 10 years. Twenty three years after the change to maize cultivation on the Rotthalmünster soil, $n$ - $\mathrm{C}_{31}$ still has a carbon isotopic composition of $-31.6 \%$, which is somewhere between the characteristic values for $C_{4}$ and $C_{3}$ vegetation but slightly closer to the latter. Although most organic molecules in soils, including $n$-alkanes and related compounds, have rather fast turnover times (e.g. Rethemeyer et al., 2004), $n$-alkanes are generally slightly more recalcitrant, showing turnover times on the order of decades (ca. 8 to 60 years in arable soils, Amelung et al., 2008 and references therein). Indeed, Wiesenberg et al. (2004) determined a turnover time of ca. 35 years for $n$ alkanes in this soil. Such a pool of slightly older $\mathrm{C}_{3}$ plantderived carbon also seems to persist in the bulk organic carbon, which, as a consequence, is also depleted in ${ }^{13} \mathrm{C}$ relative to a "typical" $\mathrm{C}_{4}$ type soil. This is consistent with work indicating that the bulk organic carbon pool in soils partially comprises an older, recalcitrant pool (Marschner et al., 2008 and references therein). Strikingly, the branched GDGT-derived alkanes ( $a$ and $b$ ) in the Rotthalmünster maize soil appear to have a dominantly $\mathrm{C}_{4}$-derived carbon isotopic composition. Specifically, their $\delta^{13} \mathrm{C}$ values are distinct from those found in $\mathrm{C}_{3}$-vegetated mineral top-soils but similar to those obtained in the Blue Range soil (Table 2); they are also enriched relative to TOC, a unique characteristic of this soil. Thus, the pool of branched GDGTs in this soil has been largely refreshed since the change to maize cultivation 23 years ago. Using the $\delta^{13} \mathrm{C}$ value of the 13,16 dimethyloctacosanes (a) from the Rotthalmünster maize soil, an estimate could be made on the turnover time of branched GDGTs. Using a $\delta^{13} \mathrm{C}$ value of $-28 \%$ o and $-15 \%$ o for $\mathrm{C}_{3}$ and $\mathrm{C}_{4}$ vegetation respectively and the average $\delta^{13} \mathrm{C}$ value of branched GDGT-derived alkanes in soils of $-28 \%$, this means that ca. $71 \%$ of the GDGTs in the maize soil is carrying a $\mathrm{C}_{4}$ carbon isotope signature $\left(F_{\text {new }}\right.$ in formula 1$)$ and ca. $29 \%$ a $\mathrm{C}_{3}$ isotope signature $\left(F_{\text {old }}\right.$ in formula 2$)$. Us- ing formulas (3) and (4) to calculate decomposition rate and turnover time, respectively, we arrive at a turnover time of ca. 19 years for branched GDGT core lipids in this arable soil in a temperate climate region.

Some further support for this estimate comes from the free-air $\mathrm{CO}_{2}$ enrichment experiment. Due to fumigation with ${ }^{13} \mathrm{C}$ depleted $\mathrm{CO}_{2}$, the $\mathrm{CO}_{2}$ above the plot was depleted by $10 \%$ relative to atmospheric $\mathrm{CO}_{2}$ and this should have an effect on the carbon isotopic composition of the vegetation growing on the plot. Indeed, Wiesenberg et al. (2008) have shown that bulk organic carbon of the vegetation on this plot was depleted by ca. 9\%o and that the vegetation derived $n$-alkanes were depleted by ca. $7 \%$ relative to the control plots. In the soil itself, however, where a pool of old carbon is present, a depletion of only $3 \%$ for the bulk carbon and $2 \%$ for the $n$-alkanes was observed. We find a similar minor depletion for the $n$-alkanes $\left(\mathrm{C}_{27}-\mathrm{C}_{33}\right)$ and TOC in this study (Table 2). In contrast, the branched GDGT-derived alkane (a) is depleted by $4.2 \%$ in the soil under elevated $\mathrm{CO}_{2}$ conditions relative to the soil under ambient $\mathrm{CO}_{2}$ conditions. This larger depletion suggests that the branched GDGT turnover has been more rapid over the 10 years of fumigation than that of the $n$-alkanes and potentially even the bulk organic carbon of the soil. It also suggests that the branched GDGTproducing bacteria consume, at least partly, labile organic matter rather than the more recalcitrant part of the TOC pool. The fact that the depletion for the GDGT-derived alkane (a) does not reach the 7 to $9 \%$ observed for the vegetation indicates that turnover has not yet completed or that not all of the organic matter consumed is fresh material. Most likely it will be a combination of both. Assuming this is only related to an incomplete turnover, we might make an estimate on the turnover time of branched GDGTs in this soil. A difference of ca. 4\%o for the 13,16-dimethyloctacosanes (a) and ca. 9\% for the bulk plant organic carbon between the FACE and control soils gives, using formula (1), a proportion of $44 \%$ of the GDGTs that has been labelled since the start of the fumigation 10 years before sampling. Using formulas (2), (3) and (4), this translates into an estimate of the turnover time for branched GDGT core lipids of ca. 17 years, which is similar to the estimate based on the $\mathrm{C}_{3} / \mathrm{C}_{4}$ vegetation change on the Rotthalmünster maize soil. Although it should be acknowledged that in both cases calculation of the turnover time depends on a single soil sample, the fact that the two, each representing a different form of labelling, arrive at a similar estimate, gives confidence that the turnover time of branched GDGT lipids in soils is near to two decades. This is faster than the turnover time of TOC and $n$-alkanes, but equal to that of carboxylic acids in the same soils (Table 3). It also supports a recent report by Peterse et al. (2010) who investigated distributions of both core GDGT lipids and intact polar lipid-derived GDGTs in a series of soil plots of which the $\mathrm{pH}$ has been manipulated for the last 45 year and concluded that the turnover time of branched GDGTs must be shorter than this 45 years. 
Table 3. Turnover time estimates (in years) for TOC, long chain odd-numbered $n$-alkanes $\left(n \mathrm{C}_{27}-n \mathrm{C}_{33}\right)$, long chain evennumbered carboxylic acids $\left(n \mathrm{C}_{22}-n \mathrm{C}_{26}\right)$ and branched GDGTderived 13,16-dimethyloctacosanes based on (natural) labelling experiments in the Rotthalmünster maize soil and the FACE soils (a in Fig. 1).

\begin{tabular}{lcccc}
\hline & TOC & $\begin{array}{c}\text { long chain } \\
n \text {-alkanes }\end{array}$ & $\begin{array}{c}\text { carboxylic } \\
\text { acids }\end{array}$ & $\begin{array}{c}13,16 \text {-dimethyl- } \\
\text { octacosane (a) }\end{array}$ \\
\hline $\begin{array}{l}\text { Rotthalmünster } \\
\text { maize soil }\end{array}$ & $40^{*}$ & $35^{*}$ & $21^{*}$ & $19^{* * *}$ \\
FACE soil & $25^{* *}$ & $55^{* *}$ & $20^{* *}$ & $17^{* * *}$ \\
\hline
\end{tabular}

* data from Wiesenberg et al. (2004)

** data from Wiesenberg et al. (2008)

*** this study

\section{Conclusions}

Compound specific $\delta^{13} \mathrm{C}$ analysis of branched GDGTderived alkanes shows that the carbon isotopic composition of branched GDGTs is similar to that of TOC. This suggests that the bacteria synthesising branched GDGTs, which might occur in the large phylum of Acidobacteria (Weijers et al., 2009), likely are heterotrophic organisms assimilating isotopically lighter and probably more labile substrates, although an autotrophic lifestyle, i.e. assimilating $\mathrm{CO}_{2}$, could not be fully excluded. Additionally, the (natural) labelling experiments studied here suggest a turnover time of ca. 18 years for branched GDGTs in arable soils in temperate climates, which is slightly shorter than for $n$-alkanes and similar to that of carboxylic acids in the same soils. Generally, this fits well in the emerging view that most microbial biomass in soils, including membrane lipids, is relatively short lived (e.g. Rethemeyer et al., 2004; Wiesenberg et al., 2008; Amelung et al., 2008 and references therein).

Acknowledgements. We are indebted to E. Krull (CSIRO) for providing a sample from the Blue Range soil and M. Lupescu (University of Bristol) for the Swedish peat sample. We are grateful to the group of J. Noesberger (ETH Zurich), M. Schmidt and A. Heim (University of Zurich) who made the samples from the Eschikon FACE experiment available. H. Flessa (von-ThuenenInstitute, Braunschweig) and R. Schnellhammer (Staatliche Höhere Landbauschule) are thanked for provision of samples from the Rotthalmünster site. I. Bull (University of Bristol) and A. Van Dijk (Utrecht University) are thanked for analytical assistance with the isotope measurements. J. S. Sinninghe Damsté is thanked for useful discussion. We thank the editor, R. Smittenberg and an anonymous reviewer for constructive comments that improved this manuscript. This research has been made possible by a Rubicon and a VENI research grant awarded to J.W.H.W. by the Netherlands Organisation for Scientific Research (NWO).

Edited by: J. Middelburg

\section{References}

Abberton, M. T., MacDuff, J. H., Marshall, A. H., and MichaelsonYeates, T. P. T.: Nitrogen fixation by hybrids of white clover (Trifolium repens L.) and Trifolium nigrescens, J. Agron. Crop. Sci., 183, 27-33, 1999.

Abelson, P. H. and Hoering, T. C.: Carbon isotope fractionation in formation of amino acids by photosynthetic organisms, Proc. Natl. Acad. Sci. USA, 47, 623-632, 1961.

Amelung, W., Brodowski, S., Sandhage-Hofmann, A., and Bol, R.: Combining biomarker with stable isotope analyses for assessing the transformation and turnover of soil organic matter, in: Advances in Agronomy, edited by: Sparks, D. L., Elsevier Inc Academic Press, Burlington, 155-250, 2008.

Berg, I. A., Kockelkorn, D., Buckel, W., and Fuchs, G.: A 3 hydroxypropionate/4-hydroxybutyrate autotrophic carbon dioxide assimilation pathway in archaea, Science, 318, 1782-1786, 2007.

Berggren, M., Laudon, H., Haei, M., Strom, L., and Jansson, M.: Efficient aquatic bacterial metabolism of dissolved lowmolecular-weight compounds from terrestrial sources, ISME J., 4, 408-416, 2010.

Bintrim, S. B., Donohue, T. J., Handelsman, J., Roberts, G. P., and Goodman, R. M.: Molecular phylogeny of Archaea from soil, Proc. Natl. Acad. Sci. USA, 94, 277-282, 1997.

Bostrom, B., Comstedt, D., and Ekblad, A.: Isotope fractionation and $\mathrm{C}-13$ enrichment in soil profiles during the decomposition of soil organic matter, Oecologia, 153, 89-98, 2007.

Boutton, T. W., Archer, S. R., Midwood, A. J., Zitzer, S. F., and Bol, R.: $\delta^{13} \mathrm{C}$ values of soil organic carbon and their use in documenting vegetation change in a subtropical savanna ecosystem, Geoderma, 82, 5-41, 1998.

Brassell, S. C., Wardroper, A. M. K., Thomson, I. D., Maxwell, J. R., and Eglinton, G.: Specific acyclic isoprenoids as biological markers of methanogenic bacteria in marine-sediments, Nature, 290, 693-696, 1981.

Cerling, T. E., Solomon, D. K., Quade, J., and Bowman, J. R.: On the isotopic composition of carbon in soil carbon dioxide, Geochim. Cosmochim. Ac., 55, 3403-3405, 1991.

Chappe, B., Michaelis, W., Albrecht, P., and Ourisson, G.: Fossil evidence for a novel series of archaebacterial lipids, Naturwissenschaften 66, 522-523, 1979.

Collister, J. W., Rieley, G., Stern, B., Eglinton, G., and Fry, B.: Compound-specific delta-C-13 analyses of leaf lipids from plants with differing carbon-dioxide metabolisms, Org. Geochem., 21, 619-627, 1994.

Copley, M. S., Berstan, R., Dudd, S. N., Docherty, G., Mukherjee, A. J., Straker V., Payne, S., and Evershed, R. P.: Direct chemical evidence for widespread dairying in prehistoric Britain, Proc. Natl. Acad. Sci. USA, 100, 1524-1529, 2003.

Crow, S. E., Sulzman, E. W., Rugh, W. D., Bowden, R. D., and Lajtha, K.: Isotopic analysis of respired $\mathrm{CO}_{2}$ during decomposition of separated soil organic matter pools, Soil Biol. Biochem., 38, 3279-3291, 2006.

DeNiro, M. J. and Epstein, S.: Mechanism of carbon isotope fractionation associated with lipid synthesis, Science, 197, 261-263, 1977.

Ehleringer, J. R., Buchmann, N., and Flanagan, L. B.: Carbon isotope ratios in belowground carbon cycle processes, Ecol. Appl., 10, 412-422, 2000. 
Gransee, A. and Wittenmayer, L.: Qualitative and quantitative analysis of water-soluble root exudates in relation to plant species and development, J. Plant Nutr. Soil Sci., 163, 381-385, 2000.

Harrod, T. R. and Hogan, D. V.: The soils of North Wyke and Rowden, Internal report, available at: http://www.northwyke.bbsrc.ac.uk/assets/pdf_files/Soils\% 20of\%20NW\%20\%20Rowden\%202.pdf, 2008.

Hayes, J. M.: Factors controlling C-13 contents of sedimentary organic-compounds - principles and evidence, Mar. Geol., 113, 111-125, 1993.

Hayes, J. M.: Fractionation of carbon and hydrogen isotopes in biosynthetic processes, in: Organic geochemistry of contemporaneous and ancient sediments, edited by: Valley, J. S. and Cole, D. R., Mineralogical Society of America, 225-277, 2001.

Hoefs, M. J. L., Schouten, S., de Leeuw, J. W., King, L. L., Wakeham, S. G., and Sinninghe Damsté, J. S.: Ether lipids of planktonic archaea in the marine water column, Appl. Environ. Microbiol., 63, 3090-3095, 1997.

Hopmans, E. C., Schouten, S., Pancost, R. D., van der Meer, M. T. J., and Sinninghe Damsté, J. S.: Analysis of intact tetraether lipids in archaeal cell material and sediments by high performance liquid chromatography/atmospheric pressure chemical ionization mass spectrometry, Rapid. Commun. Mass Spectrom., 14, 585-589, 2000.

Huang, Y., Bol, R., Harkness, D. D., Ineson, P., and Eglinton, G.: Post-glacial variations in distributions, ${ }^{13} \mathrm{C}$ and ${ }^{14} \mathrm{C}$ contents of aliphatic hydrocarbons and bulk organic matter in three types of British acid upland soils, Org. Geochem., 24, 273-287, 1996.

Huguet, C., Smittenberg, R. H., Boer, W., Sinninghe Damsté, J. S., and Schouten, S.: Twentieth century proxy records of temperature and soil organic matter input in the Drammensfjord, southern Norway, Org. Geochem., 38, 1838-1849, 2007.

John, B., Yamashita, T., Ludwig, B., and Flessa, H.: Storage of organic carbon in aggregate and density fractions of silty soils under different types of land use, Geoderma, 128, 63-79, 2005.

Kates, M., Kushner, D. J., and Matheson, A. T.: The biochemistry of Archaea (Archaebacteria), Elsevier Science Publishers, Amsterdam, 1993.

Kim, J.-H., Schouten, S., Buscail, R., Ludwig, W., Bonnin, J., Sinninghe Damsté, J. S., and Bourrin, F.: Origin and distribution of terrestrial organic matter in the NW Mediterranean (Gulf of Lion): application of the newly developed BIT index, Geochem. Geophys. Geosyst., 7, Q11017, doi:10.1029/2006GC001306, 2006.

Kissin, Y. V., Feulmer, G. P., and Payne, W. B.: Gaschromatographic analysis of polymethyl-substituted alkanes, J. Chromatogr. Sci., 24, 164-169, 1986.

Krull, E. G. and Bray, S. S.: Assessment of vegetation change and landscape variability by using stable carbon isotopes of soil organic matter, Aust. J. Bot., 53, 651-661, 2005.

Kuypers, M. M. M., Blokker, P., Erbacher, J., Kinkel, H., Pancost, R. D., Schouten, S., and Sinninghe Damsté, J. S.: Massive expansion of marine archaea during a mid-Cretaceous oceanic anoxic event, Science, 293, 92-94, 2001.

Kuzyakov, Y.: Sources of $\mathrm{CO}_{2}$ efflux from soil and review of partitioning methods, Soil Biol. Biochem., 38, 425-448, 2006.

Leininger, S., Urich, T., Schloter, M., Schwark, L., Qi, J., Nicol, G. W., Prosser, J. I., Schuster, S. C., and Schleper, C.: Archaea predominate among ammonia-oxidizing prokaryotes in soils, $\mathrm{Na}-$ ture, 442, 806-809, 2006.

Marschner, B., Brodowski, S., Dreves, A., Gleixner, G., Gude, A., Grootes, P. M., Hamer, U., Heim, A., Jandl, G., Ji, R., Kaiser, K., Kalbitz, K., Kramer, C., Leinweber, P., Rethemeyer, J., Schaeffer, A., Schmidt, M. W. I., Schwark, L., and Wiesenberg, G. L. B.: How relevant is recalcitrance for the stabilization of organic matter in soils?, J. Plant Nutr. Soil Sci., 171, 91-110, 2008.

Oppermann, B. I., Michaelis, W., Blumenberg, M., Frerichs, J., Schulz, H.-M., Schippers, A., Beaubien, S. E., and Krüger, M.: Soil microbial community changes as a result of long-term exposure to a natural $\mathrm{CO}_{2}$ vent, Geochim. Cosmochim. Ac., 74, 2697-2716, 2010.

Pancost, R. D., Coleman, J. M., Love, G. D., Chatzi, A., Bouloubassi, I., and Snape, C. E.: Kerogen-bound glycerol dialkyl tetraether lipids released by hydropyrolysis of marine sediments: A bias against incorporation of sedimentary organisms?, Org. Geochem., 39, 1359-1371, 2008.

Pancost, R. D. and Sinninghe Damsté, J. S.: Carbon isotopic compositions of prokaryotic lipids as tracers of carbon cycling in diverse settings, Chem. Geol., 195, 29-58, 2003.

Pancost, R. D., van Geel, B., Baas, M., and Sinninghe Damsté, J. S.: $\delta^{13} \mathrm{C}$ values and radiocarbon dates of microbial biomarkers as tracers for carbon recycling in peat deposits, Geology, 28, 663666, 2000.

Peterse, F., Nicol, G. W., Schouten, S., and Sinninghe Damsté, J. S.: Influence of soil $\mathrm{pH}$ on the abundance and distribution of core and intact polar lipid-derived branched GDGTs in soil, Org. Geochem. 41, 1171-1175, 2010.

Peterse, F., Schouten, S., van der Meer, J., van der Meer, M. T. J., and Sinninghe Damsté, J. S.: Distribution of branched tetraether membrane lipids in geothermally heated soils: implications for the MBT/CBT temperature proxy, Org. Geochem., 40, 201-205, 2009.

Rethemeyer, J., Kramer, C., Gleixner, G., Wiesenberg, G. L. B., Schwark, L., Andersen, N., Nadeau, M. J., and Grootes, P. M.: Complexity of soil organic matter: AMS C-14 analysis of soil lipid fractions and individual compounds, Radiocarbon, 46, 465473, 2004.

Sakata, S., Hayes, J. M., McTaggart, A. R., Evans, R. A., Leckrone, K. J., and Togasaki, R. K.: Carbon isotopic fractionation associated with lipid biosynthesis by a cyanobacterium: Relevance for interpretation of biomarker records, Geochim. Cosmochim. Ac., 61, 5379-5389, 1997.

Schouten, S., Hoefs, M. J. L., Koopmans, M. P., Bosch, H. J., and Sinninghe Damsté, J. S.: Structural characterization, occurrence and fate of archaeal ether-bound acyclic and cyclic biphytanes and corresponding diols in sediments, Org. Geochem., 29, 13051319, 1998.

Schouten, S., Hopmans, E. C., Schefuß, E., and Sinninghe Damsté, J. S.: Distributional variations in marine crenarchaeotal membrane lipids: a new tool for reconstructing ancient sea water temperatures?, Earth Planet. Sci. Lett., 204, 265-274, 2002.

Schouten, S., Strous, M., Kuypers, M. M. M., Rijpstra, W. I. C., Baas, M., Schubert, C. J., Jetten, M. S. M., and Sinninghe Damsté, J. S.: Stable carbon isotopic fractionations associated with inorganic carbon fixation by anaerobic ammoniumoxidizing bacteria, Appl. Environ. Microbiol., 70, 3785-3788, 2004. 
Sinninghe Damsté, J. S., Hopmans, E. C., Pancost, R. D., Schouten, S., and Geenevasen, J. A. J.: Newly discovered non-isoprenoid glycerol dialkyl glycerol tetraether lipids in sediments, Chem. Commun., 1683-1684, 2000.

Sinninghe Damsté, J. S., Schouten, S., Hopmans, E. C., van Duin, A. C. T., and Geenevasen, J. A. J.: Crenarchaeol: the characteristic core glycerol dibiphytanyl glycerol tetraether membrane lipid of cosmopolitan pelagic crenarchaeota, J. Lipid Res., 43, 1641-1651, 2002.

Smittenberg, R. H., Baas, M., Green, M. J., Hopmans, E. C., Schouten, S., and Sinninghe Damsté, J. S.: Pre- and postindustrial environmental changes as revealed by the biogeochemical sedimentary record of Drammensfjord, Norway, Mar. Geol., 214, 177-200, 2005.

Smittenberg, R. H., Hopmans, E. C., Schouten, S., and Sinninghe Damsté, J. S.: Rapid isolation of biomarkers for compound specific radiocarbon dating using high-performance liquid chromatography and flow injection analysis-atmospheric pressure chemical ionisation mass spectrometry, J. Chromatogr. A, 978, 129-140, 2002.

Summons, R. E., Franzmann, P. D., and Nichols, P. D.: Carbon isotopic fractionation associated with methylotrophic methanogenesis, Org. Geochem., 28, 465-475, 1998.

Teece, M. A., Fogel, M. L., Dollhopf, M. E., and Nealson, K. H.: Isotopic fractionation associated with biosynthesis of fatty acids by a marine bacterium under oxic and anoxic conditions, Org. Geochem., 30, 1571-1579, 1999.

Urich, T., Lanzen, A., Qi, J., Huson, D. H., Schleper, C., and Schuster, S. C.: Simultaneous assessment of soil microbial community structure and function through analysis of the metatranscriptome, Plos One, 3, 1-13, 2008.

van der Meer, M. T. J., Schouten, S., and Sinninghe Damsté, J. S.: The effect of the reversed tricarboxylic acid cycle on the C-13 contents of bacterial lipids, Org. Geochem., 28, 527-533, 1998.

van der Meer M. T. J., Schouten S., van Dongen D. E., Rijpstra W. I. C., Fuchs G., Sinninghe Damsté J. S., de Leeuw J. W., and Ward D. M.: Biosynthetic controls on the $\mathrm{C}-13$ contents of organic components in the photoautotrophic bacterium Chloroflexus aurantiacus. J. Biol. Chem. 276, 10971-10976, 2001.

van Dongen, B. E., Schouten, S., and Sinninghe Damsté, J. S.: Carbon isotope variability in monosaccharides and lipids of aquatic algae and terrestrial plants, Mar. Ecol.-Prog. Ser., 232, 83-92, 2002.

Wakeham, S. G., Lewis, C. M., Hopmans, E. C., Schouten, S., and Sinninghe Damsté, J. S.: Archaea mediate anaerobic oxidation of methane in deep euxinic waters of the Black Sea, Geochim. Cosmochim. Ac., 67, 1359-1374, 2003.
Weijers, J. W. H., Panoto, E., Van Bleijswijk, J., Schouten, S., Rijpstra, W. I. C., Balk, M., Stams, A. J. M., and Sinninghe Damsté, J. S.: Constraints on the biological source(s) of the orphan branched tetraether membrane lipids, Geomicrobiol. J., 26, 402-414, 2009.

Weijers, J. W. H., Schouten, S., Hopmans, E. C., Geenevasen, J. A. J., David, O. R. P., Coleman, J. M., Pancost, R. D., and Sinninghe Damsté, J. S.: Membrane lipids of mesophilic anaerobic bacteria thriving in peats have typical archaeal traits, Environ. Microbiol., 8, 648-657, 2006a.

Weijers, J. W. H., Schouten, S., Spaargaren, O. C., and Sinninghe Damsté, J. S.: Occurrence and distribution of tetraether membrane lipids in soils: Implications for the use of the TEX86 proxy and the BIT index, Org. Geochem., 37, 1680-1693, $2006 \mathrm{~b}$.

Weijers, J. W. H., Schouten, S., van den Donker, J. C., Hopmans, E. C., and Sinninghe Damsté, J. S.: Environmental controls on bacterial tetraether membrane lipid distribution in soils, Geochim. Cosmochim. Ac., 71, 703-713, 2007.

Whiticar, M. J., Faber, E., and Schoell, M.: Biogenic methane formation in marine and freshwater environments: $\mathrm{CO}_{2}$ reduction vs. acetate fermentation - Isotope evidence, Geochim. Cosmochim. Ac., 50, 693-709, 1986.

Wiesenberg, G. L. B., Gocke, M., and Kuzyakov, Y.: Fast incorporation of root-derived lipids and fatty acids into soil - Evidence from a short term multiple ${ }^{14} \mathrm{CO}_{2}$ pulse labelling experiment, Org. Geochem., 41, 1049-1055, 2010.

Wiesenberg, G. L. B., Schwarzbauer, J., Schmidt, M. W. I., and Schwark, L.: Source and turnover of organic matter in agricultural soils derived from n-alkane/n-carboxylic acid compositions and C-isotope signatures, Org. Geochem., 35, 1371-1393, 2004.

Wiesenberg, G. L. B., Schwarzbauer, J., Schmidt, M. W. I., and Schwark, L.: Plant and soil lipid modification under elevated atmospheric $\mathrm{CO} 2$ conditions: II. Stable carbon isotopic values (delta C-13) and turnover, Org. Geochem., 39, 103-117, 2008.

Wuchter, C., Schouten, S., Boschker, H. T. S., and Sinninghe Damsté, J. S.: Bicarbonate uptake by marine Crenarchaeota, FEMS Microbiol. Lett., 219, 203-207, 2003.

Xie, S., Nott, C. J., Avsejs, L. A., Maddy, D., Chambers, F. M., and Evershed, R. P.: Molecular and isotopic stratigraphy in an ombrotrophic mire for paleoclimate recontruction, Geochim. Cosmochim. Ac., 68, 2849-2862, 2004.

Zanetti, S., Hartwig, U. A., vanKessel, C., Luscher, A., Hebeisen, T., Frehner, M., Fischer, B. U., Hendrey, G. R., Blum, H., and Nosberger, J.: Does nitrogen nutrition restrict the $\mathrm{CO}_{2}$ response of fertile grassland lacking legumes?, Oecologia, 112, 17-25, 1997.

Zhang, C. L. L., Li, Y. L., Ye, Q., Fong, J., Peacock, A. D., Blunt, E., Fang, J. S., Lovley, D. R., and White, D. C.: Carbon isotope signatures of fatty acids in Geobacter metallireducens and Shewanella algae, Chem. Geol., 195, 17-28, 2003. 